\title{
Overview of energy storage technologies
}

\author{
Navid Rezaei ${ }^{1}$, Abdollah Ahmadi ${ }^{*}$, Sara N. Afifi ${ }^{3}$, Ahmed F. Zobaa ${ }^{4}$, Shady H.E. Abdel Aleem ${ }^{5}$ \\ ${ }^{1}$ Department of Electrical Engineering, University of Kurdistan, Sanandaj, Iran \\ ${ }^{2}$ The Australian Energy Research Institute and the School of Electrical Engineering and Telecommunications, \\ University of New South Wales, Sydney, NSW 2032, Australia \\ ${ }^{3}$ Scottish \& Southern Electricity Networks, Slough Depot, Chavely, slough, Berkshir, SL1 2UD, United \\ Kingdom \\ ${ }^{4}$ College of Engineering, Design \& Physical Sciences, Brunel University London, Uxbridge, UB8 3PH, United \\ Kingdom \\ ${ }^{5}$ Mathematical and Physical Sciences, 15th of May Higher Institute of Engineering, Cairo, Egypt \\ *Corresponding author: Shady H.E. Abdel Aleem, E-mail: shossam@theiet.org
}

\subsection{Introduction}

Electric power systems are gradually maturing in the operational and management architecture. The eventual goal of the system operators is to provide more reliable and high-quality energy services in a cost-effective and environmentally framework. To that end, new applications and technologies should be innovated and integrated into the system infrastructure sustainably. Evidently, one of the practical tools can help the power system to be operated in a green, qualified; the secure and economical manner is Energy Storage System (ESS). The primary motivations extend effectively the utilisation of ESS various innovations can be classified as [1]-[3]:

- Providing a high sustainable penetration of Renewable Energy Sources (RESs): Joint energy management of ESSs and RESs, by mitigating the intermittent nature of renewable resources, assures the operators to rely on higher RES penetration levels.

- Guaranteeing the system reserve requirement in a more eco-friendly portfolio: A coordinated integration of ESSs with hydro-thermal generators gets an extended spinning and non-spinning reserve capacity promising the system reliability. Besides, owing to the cleaner production of the ESS technologies, through effective lowering the share of the thermal generating units, system reserve procurement constraint is obtained in a more environment-friendly form. 
- Realisation of Electric Vehicle (EV) epidemic-applicability vision: By developing the energy storage technologies, the ever-increasing utilisation of electric vehicle can be vindicated. Furthermore, in the light of Vehicle to Grid (V2G) capability, Plug-in EVs (PEVs) can play a vital role in power system operation and management through optimal energy storage discharging.

- Development the concept of Smart/Microgrids: Efficient integration of ESS technologies allows the idea of smart grid construction to be visualised reliably. Besides, the customers can also participate in Demand Response Programs (DRPs) more dependable with least discomfort. Moreover, MicroGrids (MGs) as the smart grid flexible prosumers rely on the ESSs operative energy management ensuring a secure operation and high controllability, particularly in islanded mode.

Various types of the ESS technologies, the associated characteristics and benefits are overviewed in this section. First, a statistical analysis of the related literature is performed. Section 1.3 presents the bibliographic networks. Next, the techno-economic-environmental effects of ESSs on the power system operational aspects are discussed concisely in Section 1.4. The main technical features of ESSs will be characterised. Then the primary classification of the ESS technologies is presented and explained one-by-one in Section 1.6. Section 1.7 presents the comparison of EES technologies. In Section 1.8, some relevant conclusions and future trends are derived out.

\subsection{The statistical analysis}

This section presents statistics for documents in the field of energy storage technologies which have been published until 2017. The term of ‘energy storage technologies' has been searched in Scopus database in the article title, abstract, and keywords which resulted in 1192 documents.

Figure 1.1 illustrates that the number of publications increased from only 3 documents in 1976 to 205 documents in 2017. From the graph, it is quite clear that the number of documents has been increasing over the period.

\section{Figure 1.1 ABOUT HERE}

Figure 1.2 illustrates the numbers of documents by type; it is clear that 553 and 427 documents have been published as Articles and Conference papers respectively. 
Figure 1.3 illustrates that 628 and 606 documents have been published in Energy and Engineering subject area respectively.

Figure 1.3 ABOUT HERE

Figure 1.4 shows that 21 and 18 documents have been published with the affiliation of Chinese Academy of Sciences and Ministry of Education China respectively.

Figure 1.4 ABOUT HERE

Figure 1.5 shows that R. Teodorescu and D. Howell have published 11 and 9 documents respectively.

\section{Figure 1.5 ABOUT HERE}

Figure 1.6 shows that researchers from the United States and China have published 361 and 216 documents respectively.

Figure 1.6 ABOUT HERE

\subsection{The bibliometric networks}

This section presents the bibliometric networks using VOSVIEWER software.

\subsubsection{The co-occurrence analysis}

Figure 1.7 shows the most common keywords used in the documents by full counting method [4], [5].

\section{Figure 1.7 ABOUT HERE}

The keywords such as Energy storage and Energy Storage Technologies with red color in the middle of Figure 1.7 are the most common keywords, while the keywords such as Cathode and Anode with blue color in the outer parts are the less commonly used keywords.

Table 1.1: The ten most commonly used keywords

\begin{tabular}{ccc}
\hline Number & Keywords & Occurrences \\
\hline $\mathbf{1}$ & Energy Storage & 679 \\
\hline $\mathbf{2}$ & Energy Storage Technologies & 599 \\
\hline $\mathbf{3}$ & Electric Batteries & 212 \\
\hline $\mathbf{4}$ & Electric Energy Storage & 181 \\
\hline $\mathbf{5}$ & Renewable Energy Resources & 153
\end{tabular}




\begin{tabular}{ccc}
\hline $\mathbf{6}$ & Secondary Batteries & 140 \\
\hline $\mathbf{7}$ & Energy Storage Systems & 130 \\
\hline $\mathbf{8}$ & Wind Power & 117 \\
\hline $\mathbf{9}$ & Flywheels & 113 \\
\hline $\mathbf{1 0}$ & Electric Power Transmission Networks & 108 \\
\hline
\end{tabular}

Table 1.1 shows that Energy Storage and Energy Storage Technologies with 679 and 599 times occurrence respectively are the two top popular keywords in energy storage technologies field.

\subsubsection{The co-authorship analysis}

Table 1.2: The co-authorship analysis based on countries

\begin{tabular}{cccc}
\hline Number & Country & Documents & Citations \\
\hline $\mathbf{1}$ & The United States & 365 & 8230 \\
\hline $\mathbf{2}$ & China & 219 & 3886 \\
\hline $\mathbf{3}$ & The United Kingdom & 98 & 4064 \\
\hline $\mathbf{4}$ & Germany & 79 & 1815 \\
\hline $\mathbf{5}$ & Canada & 52 & 567 \\
\hline $\mathbf{6}$ & Spain & 42 & 1913 \\
\hline $\mathbf{7}$ & Italy & 41 & 306 \\
\hline $\mathbf{8}$ & India & 38 & 1130 \\
\hline $\mathbf{9}$ & Australia & 34 & 550 \\
\hline $\mathbf{1 0}$ & France & 32 & 699 \\
\hline
\end{tabular}

Table 1.2 illustrates the co-authorship analysis for the top ten countries with the highest number of citations. Table 1.2 shows that the United States published 365 documents and with 8230 citations is the most top country based on the co-authorship analysis.

\subsubsection{The citation analysis}

Table 1.3: The co-citation analysis based on sources

\begin{tabular}{clcc}
\hline Number & \multicolumn{1}{c}{ Source } & Documents & Citations \\
\hline $\mathbf{1}$ & Renewable and Sustainable Energy Reviews & 35 & 2880 \\
\hline $\mathbf{2}$ & Energy Conversion and Management & 16 & 1270 \\
\hline $\mathbf{3}$ & Journal of Power Sources & 24 & 1232 \\
\hline $\mathbf{4}$ & Proceeding of the IEEE & 10 & 1218 \\
\hline $\mathbf{5}$ & Science & 1 & 1201 \\
\hline $\mathbf{6}$ & Applied Energy & 34 & 973
\end{tabular}




\begin{tabular}{clll}
\hline $\mathbf{7}$ & Advanced Functional Materials & 7 & 933 \\
\hline $\mathbf{8}$ & Progress in Natural Science & 1 & 928 \\
\hline $\mathbf{9}$ & IEEE Transactions on Industrial Electronics & 1 & 463 \\
\hline $\mathbf{1 0}$ & Nature & 1 & 402
\end{tabular}

Table 1.3 shows that Renewable and Sustainable Energy Reviews with 35 documents and 2880 citations is the most relevant sources in the field of energy storage technologies.

Table 1.4: The citation analysis for the top 10 documents

\begin{tabular}{|c|c|c|c|c|c|}
\hline Number & Authors & Reference & Journal/Conference & Citation & Year \\
\hline 1 & J. Untivich et al. & [6] & Science & 1201 & 2011 \\
\hline 2 & H. Chen et al. & [1] & Progress in Natural Science & 928 & 2009 \\
\hline 3 & $\begin{array}{l}\text { C. Ponce de León et } \\
\qquad \text { al, }\end{array}$ & {$[7]$} & Journal of Power Sources & 580 & 2006 \\
\hline 4 & S. M. Hasnain & {$[2]$} & Energy Conversion and Management & 574 & 1998 \\
\hline 5 & P. F. Ribeiro et al. & [8] & Proceedings of the IEEE & 548 & 2001 \\
\hline 6 & S. Vazquez et al. & [9] & $\begin{array}{c}\text { IEEE Transactions on Industrial } \\
\text { Electronics }\end{array}$ & 463 & 2010 \\
\hline 7 & A. F. Burke & [10] & Proceedings of the IEEE & 462 & 2007 \\
\hline 8 & L. Hadjipaschalis et al. & {$[3]$} & $\begin{array}{c}\text { Renewable and Sustainable Energy } \\
\text { Reviews }\end{array}$ & 457 & 2009 \\
\hline 9 & Díaz-González et al. & [11] & $\begin{array}{c}\text { Renewable and Sustainable Energy } \\
\text { Reviews }\end{array}$ & 452 & 2012 \\
\hline 10 & $\begin{array}{l}\text { E. J. W. Crossland et } \\
\text { al. }\end{array}$ & [12] & Nature & 402 & 2013 \\
\hline
\end{tabular}

Table 1.4 shows the citation analysis of the top 10 documents with the highest number of citations. From the Table 1.4, it is clear that [6] received the highest number of citation in the field of energy storage technologies.

\subsection{ESS benefits}

Power system reliability is at risk of insecurity violation due to sudden changes in the load consumption and occurrence ' $\mathrm{N}-1$ ' contingencies. Furthermore, deployment of the RESs in energy generation causes the system behave more uncertain which lead to higher risks [13][15]. A promising tool that covers the short-term uncertainties without imposing involuntary load-shedding to the end-users or unnecessary starting-up other generating units is the 
utilisation of energy storage technologies [16]-[18]. Storage devices can be employed at different voltage levels from the generation to the distribution systems [3], [19]-[21]. Obviously, ESSs have significant impacts on system stability, security, power quality and peak load serving. In the followings, the main techno-economic advantages of ESS integration are discussed.

$\checkmark$ System reliability improvement: ESSs can enhance the reliability index of the power system by procuring a ratio of system reserve requirements. Scheduled reserve resources are deployed to mitigate the system imbalances. Spinning reserves are the fastest reserve types which provided from the free capacity of committed generators [22]. Thermal unit scheduled reserves can be replaced by ESSs. By this way, not only emission the pollutants are reduced, but also power system overall reliability is improved substantially. Furthermore, ESSs can decrease the frequency and number of energy interruptions in the distribution system and help the restoration procedures become faster and more sustainable.

One of the eventual targets of the smart grid is to construct a 'self-healing' system through which faulted elements of the system can be isolated and restored automatically and without human interposition. ESSs can perform a vital role in vindicating a selfheal power system.

$\checkmark$ Facilitating peak load energy serving: ESSs can store energy during off-peak periods and discharge during peak hours. In other words, in off-peak hours, surplus generation of Wind Turbines (WTs) and Photovoltaic panels (PVs), less-pollutant or inexpensive generators can be stored by charging the ESSs. In peak hours, instead of using high pollutant or expensive generators, ESSs can be discharged. Consequently, power system both economic and environmental indices are elevated. Furthermore, power system energy efficiency is augmented due to the more uniform load factor which is provided by arbitrating the energy from off-peak to peak hours [3].

$\checkmark$ Frequency Control: Imbalances in power system generation and consumption yield frequency excursions. Frequency deviations should be managed securely employing adequate reserve resources. Based on the fast and reliable response of the ESSs, they can be charged or discharge during frequency excursion scenarios to control the positive or negative frequency excursions. Analogously, voltage fluctuations can be regulated using the stored energy in the ESSs. Conclusively, ESSs can play a critical role in enhancing the frequency/voltage stability of the power systems. 
$\checkmark$ Power quality improvement: Variations in magnitude and shape of voltage and current waveforms referred to power quality phenomena [23]. The main issues related to the power quality phenomena are harmonics, voltage sag and swell, flickers and transients which are dominantly the resultants of the non-linear loads. ESSs can mitigate the power quality disturbances and provide qualified services without any distortions.

$\checkmark$ Cost reduction of system operational planning: ESSs can be charged when the energy price is low (usually during off-peak periods) and discharge when the market price is high. Thus, the cost of energy provision is reduced considerably. As a result, social welfare of the system is improved which is one of the eventual goals of the operators.

$\checkmark$ Generation expansion postponement: ESS utilisation, particularly during peak hours, reduces the requirements to the power-plant generations. Consequently, based on strengthening the system generation capacity, the need for installing new generation capacities is deferred and economic system indices are elevated by saving capital costs [24].

$\checkmark$ Customer cost-effective bill management: ESSs can by discharging the stored energy in peak hours when most of the expensive generating units are committed, can lowering the market prices. As a result, the consumption bill of the end-user customers reduced. This is when the market price signal can be transferred to the customers through realtime pricing mechanism and using Advanced Metering Infrastructure (AMI). Dynamic Time-of-Use (TOU) programs can also be affected by market prices. In other words, when the price signal is accessible to the customers, they can charge ESS in hours with low prices and supply their consumption demands during peak hours when energy price is high. By this way, the consumption bill is reduced. Moreover, employing ESS technologies prevents financial losses face to the consumers due to service interruptions. The financial losses are more bolded for the industrial and commercial customers.

$\checkmark$ RES generation profile leveling: Coordinated management of RES and ESS technologies can help the intermittent nature of the RES covered. The spillage of the RES output power can be stored in the ESS, and it can be discharged at hours while the output power is lower than the forecasted values. Hence, the generation profile of the RES becomes uniform. In other words, ESS motivates the operators to utilize the RES technologies with higher assurance. 


\subsection{ESS general characteristics}

Some of the performance characteristics common among all the ESS technologies are described in this section.

- Power Capacity: is defined as amount power (kW or MW) that an ESS can procure in its maximum instantaneous output.

- Energy Storage Capacity: is the amount of kWh or MWh of electrical energy an ESS can store in each period.

- Efficiency: is the ratio of recovered electricity to input electricity used to charge the ESS.

- Response Time: is time duration required for releasing full power.

- $\quad$ The Depth of Discharge $(D o D)$ : indicates how much power can be discharged during a cycle.

- Discharge Duration: the amount of time that ESS can discharge at its rated power output.

- Specific Power/Energy Density: Power output/Energy content per-unit ESS volume in W/liter or $\mathrm{J} /$ liter.

- ESS lifetime: the degradation time of ESS can be measured as calendar life and cycle life. The number of years an ESS is expected to last is its calendar life, while cycle life is predicated on how many charge-discharge cycles an ESS can be expected to procure before failure [25]. ESS lifetime affected by the type of ESS, environmental conditions, DoD and other operational parameters.

The mathematical formulation usually used to explain the general performance of the ESSs can be cast as the following:

$\operatorname{Energy}(t)=\operatorname{Energy}(t-1)+\eta_{\text {charge }}$. Power $_{\text {charge }}(t) . \Delta t-\frac{1}{\eta_{\text {discharge }}} \operatorname{Power}_{\text {discharge }}(t) . \Delta t(1.1)$

Where, Energy $(t)$, Power charge $(t)$ and Power $_{\text {discharge }}(t)$ indicate stored energy, charged power and discharged power of the ESS in period $t$, respectively. Charge and discharge efficiency of the ESS are shown by $\eta_{\text {charge }}$ and $\eta_{\text {discharge }}$, respectively. $\Delta t$ states the response time of the ESS which depends to its type.

The essential characteristics of various ESSs may be different owing to the application. Table 1.5, summarises some of the features versus ESSs applications. In Figure 1.8, the applications 
of the ESSs in different voltage levels and according to their power ratings in schematically depicted.

Figure 1.8 ABOUT HERE

Table 1.5: Key characteristics of ESS according to various applications [26]

\begin{tabular}{|c|c|c|c|c|c|}
\hline Application & ESS output & $\begin{array}{c}\text { Power Capacity } \\
\text { (MW) }\end{array}$ & $\begin{array}{l}\text { Discharge } \\
\text { Duration }\end{array}$ & Duty cycle & $\begin{array}{c}\text { Response } \\
\text { Time }\end{array}$ \\
\hline Load following & $\begin{array}{c}\text { Electricity, } \\
\text { Heat }\end{array}$ & 1 to 2000 & 15 min to 1 day & $\begin{array}{c}1 \text { to } 29 \text { times } \\
\text { per day }\end{array}$ & $\begin{array}{c}\text { Less than } 15 \\
\text { min }\end{array}$ \\
\hline Frequency control & Electricity & 1 to 2000 & 1 to $15 \mathrm{~min}$ & $\begin{array}{c}20 \text { to } 40 \text { times } \\
\text { per day }\end{array}$ & One min \\
\hline Arbitrage & Electricity & 100 to 2000 & 8 to 24 hours & $\begin{array}{c}0.25 \text { to } 1 \text { times } \\
\text { per day }\end{array}$ & $\begin{array}{c}\text { More than } 1 \\
\text { hour }\end{array}$ \\
\hline Voltage support & Electricity & 1 to 40 & $1 \mathrm{sec}$ to $1 \mathrm{~min}$ & $\begin{array}{c}10 \text { to } 100 \text { times } \\
\text { per day }\end{array}$ & msec to sec \\
\hline $\begin{array}{c}\text { Congestion } \\
\text { management }\end{array}$ & $\begin{array}{c}\text { Electricity, } \\
\text { Heat }\end{array}$ & 10 to 500 & 2 to 4 hours & $\begin{array}{l}0.14 \text { to } 1.25 \\
\text { times per day }\end{array}$ & $\begin{array}{c}\text { More than } 1 \\
\text { hour }\end{array}$ \\
\hline Asset Deferral & $\begin{array}{c}\text { Electricity, } \\
\text { Heat }\end{array}$ & 1 to 500 & 2 to 5 hours & $\begin{array}{l}0.75 \text { to } 1.25 \\
\text { times per day }\end{array}$ & $\begin{array}{c}\text { More than } 1 \\
\text { hour }\end{array}$ \\
\hline Load leveling & $\begin{array}{c}\text { Electricity, } \\
\text { Heat }\end{array}$ & 0.001 to 1 & Min to hours & $\begin{array}{c}1 \text { to } 29 \text { times } \\
\text { per day }\end{array}$ & $\begin{array}{c}\text { Less than } 15 \\
\text { min }\end{array}$ \\
\hline RES integration & $\begin{array}{c}\text { Electricity, } \\
\text { Heat }\end{array}$ & 1 to 400 & $1 \mathrm{~min}$ to hours & $\begin{array}{c}0.5 \text { to } 2 \text { times } \\
\text { per day }\end{array}$ & $\begin{array}{c}\text { Less than } 15 \\
\text { min }\end{array}$ \\
\hline $\begin{array}{c}\text { Operational } \\
\text { reserves }\end{array}$ & Electricity & 10 to 2000 & $\begin{array}{c}15 \text { min to } 2 \\
\text { hours }\end{array}$ & $\begin{array}{c}0.5 \text { to } 2 \text { times } \\
\text { per day }\end{array}$ & $\begin{array}{c}\text { Less than } 15 \\
\text { min }\end{array}$ \\
\hline
\end{tabular}

\subsection{ESS Technologies}

To store electrical energy, first, it should be converted to DC or other forms of the energy such as thermal, chemical, electrical and mechanical energies. When the stored energy is required, it should reversely convert to the AC electrical energy. From a technical point of view, ESSs have various technologies. Although, the ESS technologies are updated daily, in the following, the main ESS technologies integrated into power system different voltage levels are explained. The primary classification of ESS technologies is represented in Figure 1.9. 
In the above classification, Pumped Hydro ESS (PHESS) and Compressed Air ESS (CAESS) have both large power, greater than $50 \mathrm{MW}$, and energy storage capacities, greater than 100 MWh. Batteries are categorised into 1-50 MW power rating and 5-100 MWh energy capacities, which can be known as medium power and energy ESSs. Hydrogen ESS (HESS) and Thermal ESS (TESS) are small power and energy ESSs. Flywheel ESS (FESS), Superconducting Magnetic ESS (SMESS) and Capacitor ESS (CESS) can have large power or large energy capacity but not the both [28]. Obviously, large-scale ESSs can be used as power-plants, while the medium and small ones are useful for remote communities and electric vehicle and satellites applications [29].

The ESS technology applications should be adapted to the network where it is utilised and to the type of production it is required to be coordinated. Figure 1.10, shows the relation between the power and energy capacity of various ESS technologies and associated timescale in which they have higher performance and adaptability. For instance, PHESSs, CAESSs, Fuel Cells, TESSs and large-scale batteries are functionally most appropriated to the energy management objectives. While power quality and reliability based targets are more adapted to the SMESSs, FESSs, Super-capacitors, and batteries [29].

A preliminary comparison among the ESS technologies is listed in Table. 6. The primary applications, characteristics, and operational challenges are mentioned.

Table 1.6: ESS technologies’ applications, characteristics, and challenges [1]

\begin{tabular}{|c|c|c|c|}
\hline ESS Technology & Primary application & Characteristics & Operational Challenges \\
\hline PHESS & $\begin{array}{l}\text { 1-Energy Management } \\
\text { 2-Reserve Provision }\end{array}$ & $\begin{array}{l}\text { 1-Fast Ramp Rate } \\
\text { 2-Mature Technology } \\
\text { 3-Most economical }\end{array}$ & $\begin{array}{l}\text { 1-Geographical Restriction } \\
\text { 2-High Investment Cost } \\
\text { 3-Environmental Effects }\end{array}$ \\
\hline CAESS & $\begin{array}{l}\text { 1-Energy Management } \\
\text { 2-Reserve Provision } \\
\text { 3-RES Integration }\end{array}$ & $\begin{array}{l}\text { 1- New Technology } \\
\text { 2- Fast Ramp Rate (Faster } \\
\text { than Gas Turbines) }\end{array}$ & $\begin{array}{l}\text { 1- Geographical Restriction } \\
\text { 2- Environmental Effects } \\
\text { 3- Low response time versus to } \\
\text { FESS and Batteries }\end{array}$ \\
\hline FESS & $\begin{array}{l}\text { 1- Load Leveling } \\
\text { 2- Peak Shaving } \\
\text { 3- Transient Stability } \\
\text { 4- Frequency Regulation }\end{array}$ & $\begin{array}{l}\text { 1-Modular Technology } \\
\text { 2-Free size } \\
\text { 3-Long Lifetime } \\
\text { 4-Fast response time } \\
\text { 5- High Efficiency } \\
\text { 6- High Power without } \\
\text { excessive heating }\end{array}$ & $\begin{array}{l}\text { 1-Constructional Limitations } \\
\text { 2-Long recharging time due to } \\
\text { high frictional losses }\end{array}$ \\
\hline
\end{tabular}




\begin{tabular}{|c|c|c|c|}
\hline SMESS & $\begin{array}{l}\text { 1-Power Quality } \\
\text { 2-Frequency Regulation }\end{array}$ & 1-Highest Efficiency & $\begin{array}{l}\text { 1-Low Energy Density } \\
\text { 2-Expensive of materials } \\
\text { 3-Manufacturing Complexity }\end{array}$ \\
\hline Super-Capacitor & $\begin{array}{l}\text { 1-Power Quality } \\
\text { 2-Frequency Regulation }\end{array}$ & $\begin{array}{l}\text { 1-Long Lifetime } \\
\text { 2-Fast Discharge }\end{array}$ & 1-High Operational Costs \\
\hline TESS & $\begin{array}{l}\text { 1-Load Leveling } \\
\text { 2-Load Management } \\
\text { 3-Grid Stability }\end{array}$ & 1-Very High Energy Density & 1-High Operational Costs \\
\hline Batteries & $\begin{array}{l}\text { 1-Power Quality } \\
\text { 2-Congestion relief } \\
\text { 3-Grid Stability } \\
\text { 4-Load Leveling } \\
\text { 5-RES Integration }\end{array}$ & $\begin{array}{l}\text { 1- Long Lifetime } \\
\text { 2-Mature Technology } \\
\text { 3-Fast Response Time } \\
\text { 4-Good Scaling Potential }\end{array}$ & $\begin{array}{l}\text { 1- Discharge Restriction } \\
\text { 2-Lower Energy Density } \\
\text { 3-Emission Footprint } \\
\text { 4-Sensitive to Heat }\end{array}$ \\
\hline Flow Batteries & $\begin{array}{l}\text { 1-Fast Ramp Rate } \\
\text { 2-Peak Shaving } \\
\text { 3-Frequency Regulation } \\
\text { 4-Power Quality }\end{array}$ & $\begin{array}{l}\text { 1-Very Long Lifetime } \\
\text { 2-Lower Efficiency }\end{array}$ & $\begin{array}{l}\text { 1-Developing Technology } \\
\text { 2-Design Complexity } \\
\text { 3-Lower Energy Density }\end{array}$ \\
\hline
\end{tabular}

Figure 1.10 ABOUT HERE

- PHESSs: PHESSs are the oldest and largest ESSs in power systems. As depicted in Figure 1.11, pumped hydro storage units usually have two lavers, one in high altitude and other in low height. In peak hours, the stored water in the upper pool is released, and its height dependent potential energy is converted to kinetic energy using turbines at lower pool. The coupled turbines and synchronous generators convert the mechanical energy to the electrical one [31, 32].

During off-peak hours the pumps are activated and transferred the reserved water from the lower pool to the upper one. Accordingly, it avoids the system experiencing overfrequency states. Moreover, since valley filling and peak shaving procedures are executed in a 24-hour operational period, PHESSs help the consumption profile being flatter. The performance of a typical PHESS is depicted over a daily operating period is presented in Figure 1.11, Worth mentioning that, the typical PHESS capacity rating is $1000 \mathrm{MW}$ with 75 per cent to 82 per cent efficiency. The height difference between the upper and lower reservoir should be at least 300 meters such a way that the PHESS construction is justified. The calendar life of PHESSs is 80 years. 
The PH-ESSs are good candidates to be coordinated with base-load generation units such as nuclear power-plants. In off-peak hours, when it is not techno-economic to OFF the nuclear units, PH-ESSs can go to pumping mode and enhance the efficiency of the nuclear units. Vice-versa, in peak hours the nuclear units can supply the required energy to run the generating mode.

Coordinated energy management between PHESSs and WTs plays a vital role in RES higher integration and power system economical operational planning.

\section{Figure 1.11 ABOUT HERE}

- Compressed Air ESS: CAESS main components usually include compressor, air storage cavern, combustion chamber, and turbine-generator set [33]. In this system, air is compressed up to 75 bars during off-peak periods in a hypogeal reservoir (cavern). By this way, electric energy is converted to pressurised potential energy and stored in the reservoir. In peak periods, the converted energy is released from the cavern and combined with fuel in the combustion chamber and used to generate electrical energy in the turbine-generator set. The cavern can be constructed artificially which is very costly or can be located in salt caverns, underground water reservoirs or hard rock mines. The compressed air ESSs can be constructed in small size to large-scale units. They usually have more than $100 \mathrm{MW}$ power rating with 70 per cent to 80 per cent efficiency and $12 \mathrm{kWh} / \mathrm{m}^{3}$ energy density [30]. Two $290 \mathrm{MW}$ and $110 \mathrm{MW}$ CAESS units are currently built in Germany and USA, respectively. Figure 1.12, shows the structure and necessary components of a typical CAESS.

\section{Figure 1.12 ABOUT HERE}

- Flywheel ESS: Electrical energy is stored in the rotor inertia through accelerating the rotor to very high speeds [34]. The stored kinetic energy is dependable to the squared speed. The lighter the rotor leads, the higher speed and upper energy storage capability. Therefore, it is tried to use light materials in the structure of the rotor such new composites. In the charging mode (during off-peak), the flywheel plays as a motor, while it is likewise a generator in the discharging mode (in peak periods). In the generating mode, the stored mechanical energy is depleted gradually by reduction the rotor speed. The maintenance costs of the flywheels are relatively low, and this makes them more attractive. The typical efficiency of FESS state-of-the-art technology is higher than 90 per cent. 
FESSs suffer from frictional losses due to the bearings. To eliminate the losses, the vacuum enclosure and magnetic bearings are utilised. Therefore, although the safety and economic aspects may be degraded, the new FESSs become more efficient and compact with no noises.

One of the exciting applications of the FESS technology is providing virtual inertia, which is mainly, very critical in islanded microgrids (MGs) with dominantly inertialess inverter-interfaced distributed generations. In this way, the MG frequency stability and damping margins can be ensured.

In Figure 1.13, a typical FESS model with its power conditioning inverters are depicted.

Figure 1.13 ABOUT HERE

- Batteries: Substantially, electrochemical storages based on the energy conveying material storage method is divided into two main categories: Internal and External. In external storages, the reactant material section and electric power generating section is designed independently. The hydrogen and methane gas storages are included in external storage category. In internal storages, both the two reactant material and power generating sections are located in one common volume. In Figure 1.14, classification of electrochemical ESSs is illustrated [35]. Although batteries are reversible electrochemical cells, there have been various technologies to produce them as ESSs.

\section{Figure 1.14 ABOUT HERE}

Currently, batteries are best options for energy storing in the medium and small sizes. These ESSs have two electrodes and betwixt electrolyte. In charging mode, the ions move from anode to cathode. A reverse moving is performed during the discharging mode. Indeed, energy is stored in batteries electrochemically through creating electrically charged ions. A wide range of battery technologies is fabricated in the industry such as lead-acid, lithium-ion, nickel-cadmium, sodium-sulphur, sodiumnickel-chloride, zinc-air, etc. Batteries are relatively inexpensive, and most of them have a matured technology. They can be applied in either portable or permanent application. Large-scale batteries can be utilised in system emergency control actions and providing back-up for higher RES integration [30]. When the power system experiences a contingency or disturbance, it may transfer to the emergency state. Batteries can preserve the system stability limitations in the acceptable ranges and evoke it to the normal state. In an economic point of view, batteries can buy energy in hours with low market prices and sell the stored energy at hours when the price is high. Through this arbitrage, they can provide considerable revenues for the operators. 
Besides, they have also an advantageous role in providing higher load factor. Medium size batteries are beneficial for supplying hybrid electric vehicle and electric ship requirements.

In lithium-ion batteries, the cathode is made from a combination of lithium such as lithium-cobalt-oxide and anode is made from carbon. The electrolyte is made of the lithium salt in an organic solvent. The efficiency of lithium-ion batteries is about 85 per cent with $300 \mathrm{Wh} /$ liter energy density. The cycle life is about 1000 to 5000 cycles. The DoD is up to 100 per cent. Recently, nano-materials have considerable impacts on the development of lithium-ion batteries.

In lead-acid batteries, electrodes are lead, and antipodean metals dipped in sulphuric acid as the electrolyte. Exchange of negative and positive ions between anode and cathode in the electrolyte is the basis of the battery charge and discharge. The efficiency of lead-acid batteries is about 80 per cent with $100 \mathrm{Wh} /$ liter energy density. The cycle life is about 500 to 2000 cycles. Their DoD is 70 per cent.

In sodium-sulphur batteries, the electrolyte is made of liquid sodium and liquid sulphur with solid beta alumina. The charge and discharge process is likewise the lithium-ion batteries. Energy density in sodium-sulphur batteries is three times of the lead-acid storages. Sodium-sulphur batteries can efficiently work under high-temperature conditions about $600{ }^{\circ} \mathrm{F}$. The efficiency is about 80 per cent with $250 \mathrm{Wh} /$ liter energy density and 5000 to 10000 cycles lifecycle. DoD is 100 per cent.

Flow batteries are rechargeable, low cost and useful technologies for sustainable energy storage. In flow batteries, the electrolyte is kept in an external vessel. Ion exchange between two distinctive electrolytes results in electricity generation. The power output of these batteries is in the range of $\mathrm{kW}$ to MW. Despite low energy density and high cost due to structure complexity, the main advantages of the flow batteries are very fast charge/discharge process, high power and energy ratings, a long lifetime by proper maintenance, use of nontoxic materials and controllable electricity generation. The efficiency of typical flow batteries is about 75 per cent. Figure 1.15, represents the basic structure of the flow batteries.

Figure 1.15 ABOUT HERE

Different types of the flow batteries are mainly developed based on bromine combinations such as zinc $(\mathrm{ZnBr})$, sodium $(\mathrm{NaBr})$, vanadium $(\mathrm{VBr})$ and sodium polysulfide. Charge and discharge procedures can be reversed using electrochemical reactions through a cell membrane. 
- Superconducting Magnetic ESSs: Superconducting materials extend the storage capacity and at low temperatures has no resistance against the current. In SMESSs, the goal is to store electric energy in a magnetic field which is produced using a superconducting coil conveying a DC. The response rate of SMESSs is lower than 100 ms which is relatively fast. This makes them appropriate candidates for regulating distribution power system stability and utilisation as power quality conditioners. Their capacity rating is up to $3 \mathrm{MW}$ with more than 90 per cent efficiency.

SMESSs consist of three essential parts: superconducting coil, cooling system, power conditioner system. The superconductivity feature of the coil leads to negligible losses and the passing DC remained unchanged for extended times. To sustain the coil superconductivity feature, the cooling system reduces the temperature to $50-77^{\circ} \mathrm{K}$. The power conditioner system is employed to convert the AC to the DC and vice versa. The switching process of the internal inverters is controlled to have the required output. Figure 1.16, shows a typical structure of a SMESS.

Figure 1.16 ABOUT HERE

Due to high required energy for the cooling system and high costs of the superconducting coils, currently, SMESSs are used for short-term energy storing and regarding the power quality targets. Amount of stored energy is a function of coil inductance and its passing current. The higher inductance means higher capital costs. Usually, in the SMESSs, 70 per cent of the overall costs belong to power conditioner system. In 2018, a SMESS has 35000\$/kW cost which relatively high.

- Super-Capacitors: In the super-capacitors, the energy is stored in the electric field between two electrodes. They may have a volume thousand times larger than a capacitor, and their energy density is much higher. The largest super-capacitor has an energy density of $0.03 \mathrm{kWh} / \mathrm{kg}$. They have high permeability and very adjacent electrodes with a longer lifetime. Electric Double Layer Capacitors (ELDCs) with very high power density, low internal resistance, and high efficiency higher than 95 per cent are the most common super-capacitors. The super-capacitors can be utilised in military lasers, medical equipment, wind turbines, solar systems, electromagnetic drivers, microwaves, large LED drivers and hybrid electric vehicles. Numerically, cycle life and calendar life of the super-capacitors are one million and 15 years, respectively. DoD index is 75 per cent. Super-capacitors have $2 \mathrm{Wh} /$ liter to $10 \mathrm{Wh} /$ liter energy density and up to $15 \mathrm{~kW} /$ liter power density [35]. 
In small scales, super-capacitors are operated for energy saving. If the energy density has been developed, it is expected that electrochemical batteries replaced by supercapacitors.

- Thermal ESSs (TESSs): Energy can be stored in thermal ESSs using three methodologies:

(a) Energy storage through heating a liquid or solid without state change. It is a sensible heat TESS which is relying on the temperature of the underlying material. Insensible TESSs stored energy is utilised for both heating and cooling purposes. This system allows peak shifting and leads a more uniform load factor. During offpeak hours, the interfacing material may be heated or cooled, and in peak hours the appropriate heating or cooling can be reached through blowing the air on the interfacing material. The interfacing material can be water, underground layers and building a concrete foundation. The energy density of the sensible TESS is typically $25 \mathrm{kWh} / \mathrm{m}^{3}$. The main advantages of this ESS are clean and reliable heating and cooling, low power output oscillations [30, 35].

(b) Energy storage through heating a material whose state is altered. It is a latent heat TESS. The amount of stored energy depends on the latent heat of utilised material and associated mass. The interfacing material used in latent TESSs should have the capability of the phase changing during charges and discharges such paraffin and water. Since there is no temperature change in the interfacing material during the phase change, the constant temperature during discharging is the main advantage of latent TESSs [30].

(c) Energy storage through providing required heat to activate a physical or chemical process. It is known as electrochemical heat TESS. The process is performed in a thermally insulated container such that the thermal energy can be stored efficiently. Hydrogen can be used in electrochemical TESS as hydrogen ESS (HESS). Based on the electrochemical process of the electrolyte, the electrical energy can be stored in the form of the chemical energy and discharged vice-versa. The conversion is by ion transfer between electrochemical cells using water electrolysis. The produced hydrogen is compressed and stored in pressurised buffer tanks. The stored hydrogen can be used in Fuel Cells (FCs), residential consumers, expansive turbines, and hydrogen-based hybrid electric vehicles. HESSs are good candidates for isolated and remote power systems, in particular, to mitigate intermittencies of RESs. Figure 1.17, illustrates the process of generating hydrogen and its applications. 
Figure 1.17 ABOUT HERE

The low density of gaseous hydrogen restricts its application. Consequently, the liquid hydrogen due to its higher energy density is considered. Storage of liquid hydrogen requires insulated cryogenic freezing processes which are very costly. Moreover, the life expectancy is a constraint affects power network applications of the HESSs.

(d) Recently, ice-storage technology is introduced as an innovative ESS. In off-peak electric energy is used to freeze the water in an insular tank. In peak hours the stored ice is utilised as a cooling system. Ice-storage has excellent effects on comfort index of the consumers can be used as heater/chiller systems in various seasons.

\subsection{Comparison of ESS technologies}

In this section, ESS various technologies are compared subject to different techno-economic indices. Worth mentioning, there is no ideal ESS technology which can meet all the requirements of power system applications. Apparently, the ideal ESS is that have the more significant capacity, higher density, higher efficiency, lower cost and longer lifetime, however, so far none of the ESS technologies can satisfy all the ideal indices simultaneously [36]. Evidently, ESSs can be utilised in all parts of the power system infrastructure from generation to consumption. Accordingly, to select a more appropriate technology, power system operators should consider some key aspects such as economic, environmental, security, stability, optimal size and location, the system voltage level and ESS response time concurrently. Where the high storage capacity is required, the PHESS, CAESS, and TESS can be selected by operators, while the battery and ice storage technologies are more effective in low-voltage power systems and particularly in islanded MGs. For instance, the PHESS and TESS technologies are suited for application in the generation side. In the transmission and distribution levels, the battery and FESS technologies are good candidates. In the consumption level, battery, ice-storage, some of the TESS technologies can be considered.

\subsubsection{Technology maturity level}

In Figure 1.18, ESS technologies are assessed from the maturity view of the point concerning capital requirements and technology risk indices. The ESSs are classified into developing, developed and mature categories [26]. PHESS, CAESS and lead-acid have mature technologies and low investment and technical risks. FESS, ice-storage, sodium-sulphur and lithium-ion 
batteries are developed while the super-capacitors, SMESS, HESS, TESS and flow batteries are in the way of development.

Figure 1.18 ABOUT HERE

ESS technology commercialisation versus to the power capacity is demonstrated in Figure 1.19. Obviously, PHESS has the fully commercialised while the SMESS and super-capacitor technologies are brand-new small-scale technologies.

\section{Figure 1.19 ABOUT HERE}

Indeed PHESS are the best options for the bulk power system optimisation issues due to high capacity and owing to discharge time at rated power [37].

\subsubsection{ESS costs}

To compare the operational costs of the ESS technologies, device efficiency, energy/power investment cost and calendar/cycle lifetime should be considered simultaneously. Table 1.7, summarizes the ESS technology substantial cost parameters [38].

Table 1.7: Comparison of various ESS technologies considering to operational cost parameters

\begin{tabular}{|c|c|c|c|c|c|c|c|c|c|c|}
\hline \multirow[b]{2}{*}{$\begin{array}{l}\text { Technolog } \\
\text { y }\end{array}$} & \multicolumn{3}{|c|}{ Investment cost } & \multicolumn{2}{|c|}{$\begin{array}{l}\text { Calendar and } \\
\text { cycle lifetime }\end{array}$} & \multirow[b]{2}{*}{$\begin{array}{c}\text { Efficienc } \\
\text { y (\%) }\end{array}$} & \multicolumn{4}{|c|}{ Energy and power density } \\
\hline & $\$ / \mathrm{kW}$ & $\begin{array}{c}\$ / \mathrm{kW} \\
\mathrm{h}\end{array}$ & $\begin{array}{l}\text { cent/kWh } \\
\text {-per cycle }\end{array}$ & $\begin{array}{l}\text { Calenda } \\
\text { r } \\
\text { lifetime } \\
\text { (years) }\end{array}$ & $\begin{array}{c}\text { Cycle } \\
\text { lifetime } \\
\text { (cycles) }\end{array}$ & & $\begin{array}{c}\text { Wh/k } \\
\text { g }\end{array}$ & $\mathrm{W} / \mathrm{kg}$ & $\begin{array}{c}\text { Wh/ } \\
\text { L }\end{array}$ & $\mathrm{W} / \mathrm{L}$ \\
\hline PHESS & $\begin{array}{l}600- \\
2000\end{array}$ & $5-100$ & $0.1-1.4$ & $40-60$ & - & $75-85$ & $\begin{array}{l}0.5- \\
1.5\end{array}$ & - & - & $0.5-1.5$ \\
\hline CAESS & $\begin{array}{l}400- \\
800\end{array}$ & $2-50$ & $2-4$ & $20-40$ & - & $40-55$ & $30-60$ & - & $3-6$ & $0.5-2$ \\
\hline Lead-acid & $\begin{array}{l}300- \\
600\end{array}$ & $\begin{array}{l}200- \\
400\end{array}$ & $20-100$ & $5-15$ & $\begin{array}{l}500- \\
1000\end{array}$ & $60-94$ & $30-50$ & $75-300$ & $\begin{array}{l}50- \\
80\end{array}$ & $10-400$ \\
\hline NaS & $\begin{array}{l}1000- \\
3000\end{array}$ & $\begin{array}{l}300- \\
500\end{array}$ & $8-20$ & $10-15$ & 2500 & $85-90$ & $\begin{array}{l}150- \\
240\end{array}$ & $\begin{array}{l}150- \\
230\end{array}$ & $\begin{array}{l}150- \\
250\end{array}$ & - \\
\hline Li-ion & $\begin{array}{l}1200- \\
4000\end{array}$ & $\begin{array}{l}600- \\
2500\end{array}$ & $15-100$ & $5-15$ & $\begin{array}{c}1000- \\
10000+\end{array}$ & $85-100$ & $\begin{array}{l}75- \\
200\end{array}$ & $\begin{array}{l}150- \\
315\end{array}$ & $\begin{array}{l}200- \\
500\end{array}$ & - \\
\hline $\begin{array}{l}\text { Flow } \\
\text { Batteries }\end{array}$ & $\begin{array}{l}700- \\
2500\end{array}$ & $\begin{array}{l}150- \\
1000\end{array}$ & $5-80$ & $5-15$ & $\begin{array}{c}2000- \\
12000+\end{array}$ & $70-75$ & $10-50$ & - & $\begin{array}{l}16- \\
60\end{array}$ & - \\
\hline SMESS & $\begin{array}{l}200- \\
300\end{array}$ & $\begin{array}{l}1000- \\
10000\end{array}$ & - & $20+$ & $\begin{array}{c}100000 \\
+\end{array}$ & 95 & $0.5-5$ & $\begin{array}{l}500- \\
2000\end{array}$ & $\begin{array}{l}0.2- \\
2.5\end{array}$ & $\begin{array}{l}1000- \\
4000\end{array}$ \\
\hline FESS & $\begin{array}{l}250- \\
350\end{array}$ & $\begin{array}{l}1000- \\
5000\end{array}$ & $3-25$ & 15 & $20000+$ & $85-92$ & $10-30$ & $\begin{array}{l}400- \\
1500\end{array}$ & $\begin{array}{l}20- \\
80\end{array}$ & $\begin{array}{l}1000- \\
2000\end{array}$ \\
\hline $\begin{array}{l}\text { Super- } \\
\text { capacitor }\end{array}$ & $\begin{array}{l}100- \\
300\end{array}$ & $\begin{array}{l}300- \\
2000\end{array}$ & $2-20$ & 5 & $50000+$ & $85-97$ & $0.05-5$ & $\begin{array}{c}10000 \\
0\end{array}$ & $2-10$ & $\begin{array}{c}100000 \\
+\end{array}$ \\
\hline
\end{tabular}




\begin{tabular}{|c|c|c|c|c|c|c|c|c|c|c|}
\hline TESS & $\begin{array}{l}200- \\
300\end{array}$ & $20-60$ & $2-4$ & $5-20$ & - & $20-50$ & $\begin{array}{l}80- \\
200\end{array}$ & - & $\begin{array}{l}80- \\
500\end{array}$ & - \\
\hline HESS & $\begin{array}{c}10000 \\
+\end{array}$ & - & $\begin{array}{l}6000- \\
20000\end{array}$ & $5-15$ & $10000+$ & $20-50$ & $\begin{array}{c}800- \\
10000\end{array}$ & $500+$ & $\begin{array}{l}500- \\
3000\end{array}$ & $500+$ \\
\hline
\end{tabular}

\subsection{Conclusions and Future Trends}

In this section, the critical ESS technologies have been reviewed. With the increase of the RES penetration, ESSs can provide a sustainable integration of renewable in a techno-economic portfolio. Both technical and economic advantages of various ESSs have been reviewed. The details of each technology discussed concisely and compared to other ones. Based on the review, the following concluding remarks could be derived out [30]:

- There is no ESS technology which can meet the ideal storage requirements of the power system. Some of the technologies are mature and cost-effective such as PHESSs.

- The ESS can be classified as high-efficiency technologies with higher than 90 per cent. Some of them are low efficient below the 50 per cent like the HESS which motivates to higher research and development.

- In the selection of optimal ESS technologies, the capital costs, the lifetimes, the energy and power densities and environmental footprints should be considered concurrently.

As future trends, smart energy storage systems (SESSs) with intelligent, controllable and flexible charging/discharging procedure are innovative levels of technological progress in the field of the ESSs. SESSs have considerable impacts on the reliable integration of Plug-in Hybrid Electric Vehicle (PHEVs) with the capability of providing Vehicle to Grid (V2G) and Grid to Vehicle (G2V) systems. Furthermore, SESSs can help the government around the world to develop in smart grid evolution. One of the imperative tools is realising the MG concept at the distribution level. SESSs can ensure sustainable operation of the MGs, particularly in the islanded mode. Coordinated energy management strategy of distributed generation and ESSs is a critical function in the MG Central Controller (MGCC) control panel.

As one the innovations in the SESS category, we can refer to the Electric Springs. The principle of electric springs is dual to mechanical springs and based on Hook law, i.e., $F=-k x$. Where, $x$ is the physical displacement of spring through which potential energy, $\left(P E=\frac{1}{2} k x^{2}\right)$, can be stored or released by spring. Analogously, using the power-electronic static switches, the concept of electric springs are identified [39] which follows the $q=-C V$ relation. Through charging or discharging the electric springs are transferred to capacitive or inductive modes 
and the electric energy can be stored or released, respectively. For example, when the system voltage is deviated from the set-point reference value the spring is changed to charge or discharge modes to regulate the power system voltage level. In Figure 1.20, the structure of an electric spring, equivalent circuit and operating modes are represented.

\section{Figure 1.20 ABOUT HERE}

To reach to a near ideal ESS, the operators can combine the ESS technologies in an integrated and controllable hybrid ESS. It also needs insight into both power system and ESS technical aspects to provide efficient hybrid ESS technology. ESS can also combine with Distribution Flexible AC Transmission Systems (D-FACTS) devices to enhance the reliable performance and strengthen the compensation targets. Another exciting research topic is optimisation of distributed ESSs type, size, and location in MGs.

\subsection{References}

[1] H. Chen, T. N. Cong, W. Yang, C. Tan, Y. Li, and Y. Ding, 'Progress in electrical energy storage system: A critical review’. Progress in Natural Science. 2009;19(3):291-312.

[2] S. M. Hasnain, 'Review on sustainable thermal energy storage technologies, Part I: heat storage materials and techniques'. Energy Conversion and Management. 1998; 39(11):112738.

[3] I. Hadjipaschalis, A. Poullikkas, and V. Efthimiou, 'Overview of current and future energy storage technologies for electric power applications'. Renewable and Sustainable Energy Reviews. 2009;13(6):1513-22.

[4] A. Perianes-Rodriguez, L. Waltman, and N. J. van Eck, 'Constructing bibliometric networks: A comparison between full and fractional counting'. Journal of Informetrics. 2016;10(4):1178-95.

[5] L. Leydesdorff and H. W. Park, 'Full and fractional counting in bibliometric networks'. ArXiv preprint arXiv:1611.06943, 2016.

[6] J. Suntivich, K. J. May, H. A. Gasteiger, J. B. Goodenough, and Y. Shao-Horn, 'A Perovskite Oxide Optimized for Oxygen Evolution Catalysis from Molecular Orbital Principles'. Science. 2011;334(6061):1383-85.

[7] C. Ponce de León, A. Frías-Ferrer, J. González-García, D. A. Szánto, and F. C. Walsh, 'Redox flow cells for energy conversion'. Journal of Power Sources. 2006;160(1):716-32.

[8] P. F. Ribeiro, B. K. Johnson, M. L. Crow, A. Arsoy, and Y. Liu, 'Energy storage systems for advanced power applications'. Proceedings of the IEEE. 2001; 89(12):1744-56.

[9] S. Vazquez, S. M. Lukic, E. Galvan, L. G. Franquelo, and J. M. Carrasco, 'Energy Storage Systems for Transport and Grid Applications'. IEEE Transactions on Industrial Electronics. 2010;57(12):3881-95.

[10] A. F. Burke, 'Batteries and Ultracapacitors for Electric, Hybrid, and Fuel Cell Vehicles'. Proceedings of the IEEE. 2007;95(4):806-20.

[11] F. Díaz-González, A. Sumper, O. Gomis-Bellmunt, and R. Villafáfila-Robles, 'A review of energy storage technologies for wind power applications'. Renewable and Sustainable Energy Reviews. 2012;16(4):2154-71.

[12] E. J. W. Crossland, N. Noel, V. Sivaram, T. Leijtens, J. A. Alexander-Webber, and H. J. Snaith, 'Mesoporous TiO2 single crystals delivering enhanced mobility and optoelectronic device performance'. Nature. 2013;495:215. 
[13] M. Hasheminamin, V. G. Agelidis, A. Ahmadi, P. Siano, and R. Teodorescu, 'Single-point reactive power control method on voltage rise mitigation in residential networks with high PV penetration'. Renewable Energy. 2018;119:504-12.

[14] M. Charwand, A. Ahmadi, P. Siano, V. Dargahi, and D. Sarno, 'Exploring the trade-off between competing objectives for electricity energy retailers through a novel multi-objective framework'. Energy Conversion and Management. 2015;91:12-8.

[15] H. Moghimi, A. Ahmadi, J. Aghaei, and A. Rabiee, 'Stochastic techno-economic operation of power systems in the presence of distributed energy resources'. International Journal of Electrical Power \& Energy Systems. 2013;45(1):477-88.

[16] A. Rezvani, M. Gandomkar, M. Izadbakhsh, and A. Ahmadi, 'Environmental/economic scheduling of a micro-grid with renewable energy resources'. Journal of Cleaner Production. 2015;87:216-26.

[17] M. Izadbakhsh, M. Gandomkar, A. Rezvani, and A. Ahmadi, 'Short-term resource scheduling of a renewable energy based micro grid'. Renewable Energy. 2015;75:598-606.

[18] M. Khalid, A. Ahmadi, A. V. Savkin, and V. G. Agelidis, 'Minimising the energy cost for microgrids integrated with renewable energy resources and conventional generation using controlled battery energy storage'. Renewable Energy. 2016;97:646-55.

[19] S. Koohi-Kamali, V. V. Tyagi, N. A. Rahim, N. L. Panwar, and H. Mokhlis, 'Emergence of energy storage technologies as the solution for reliable operation of smart power systems: A review’. Renewable and Sustainable Energy Reviews. 2013;25:135-65.

[20] X. Tan, Q. Li, and H. Wang, 'Advances and trends of energy storage technology in Microgrid’. International Journal of Electrical Power \& Energy Systems. 2013;44(1):179-91.

[21] D. O. Akinyele and R. K. Rayudu, 'Review of energy storage technologies for sustainable power networks'. Sustainable Energy Technologies and Assessments. 2014;8:74-91.

[22] A. Ahmadi, J. Aghaei, and H. A. Shayanfar, 'Stochastic self-scheduling of hydro units in joint energy and reserves markets'. in 2011 19th Iranian Conference on Electrical Engineering, 2011. pp. 1-5.

[23] F. H. Gandoman et al., 'Review of FACTS technologies and applications for power quality in smart grids with renewable energy systems'. Renewable and Sustainable Energy Reviews. 2018;82:502-14.

[24] H. Mavalizadeh, A. Ahmadi, F. H. Gandoman, P. Siano, and H. A. Shayanfar, 'Multiobjective Robust Power System Expansion Planning Considering Generation Units Retirement'. IEEE Systems Journal. 2017; Early Acess:1-12.

[25] H. L. Ferreira, R. Garde, G. Fulli, W. Kling, and J. P. Lopes, 'Characterisation of electrical energy storage technologies’. Energy. 2013;53:288-98.

[26] M. C. Lott, S.-I. Kim, C. Tam, D. Houssin, and J. Gagné, 'Technology roadmap: energy storage'. International Energy Agency; Paris. 2014.

[27] J. Eyer, G. Corey, and S. N. Laboratories, 'Energy Storage for the Electricity Grid: Benefits and Market Potential Assessment Guide : a Study for the DOE Energy Storage Systems Program'. Sandia National Laboratories;2010.

[28] D. Connolly, 'A review of energy storage technologies'. Ireland: University of Limerick, 2009.

[29] S. Sabihuddin, A. Kiprakis, and M. Mueller, 'A Numerical and Graphical Review of Energy Storage Technologies’. Energies. 2015;8(1):p. 172-216.

[30] 'Grid Energy Storage'. U.S. Department of Energy;2013.

[31] A. Esmaeily, A. Ahmadi, F. Raeisi, M. R. Ahmadi, A. Esmaeel Nezhad, and M. Janghorbani, 'Evaluating the effectiveness of mixed-integer linear programming for day-ahead hydrothermal self-scheduling considering price uncertainty and forced outage rate'. Energy. 2017;122:182-93.

[32] A. Ahmadi, J. Aghaei, H. A. Shayanfar, and A. Rabiee, 'Mixed integer programming of multiobjective hydro-thermal self scheduling'. Applied Soft Computing. 2012;12(8):2137-46.

[33] S. Shafiee, H. Zareipour, A. M. Knight, N. Amjady, and B. Mohammadi-Ivatloo, 'RiskConstrained Bidding and Offering Strategy for a Merchant Compressed Air Energy Storage Plant'. IEEE Transactions on Power Systems. 2017;32(2):946-57. 
[34] B. Bolund, H. Bernhoff, and M. Leijon, 'Flywheel energy and power storage systems'. Renewable and Sustainable Energy Reviews. 2007;11(2):235-58.

[35] A. F. Zobaa. Energy storage-technologies and applications. Croatia: InTech Publisher; 2013.

[36] S. C. Smith, P. K. Sen, and B. Kroposki, 'Advancement of energy storage devices and applications in electrical power system'. in 2008 IEEE Power and Energy Society General Meeting - Conversion and Delivery of Electrical Energy in the 21st Century. 2008; pp. 1-8.

[37] H. Akbari and O. Sezgen, 'Performance evaluation of thermal energy storage systems'. Energy and Buildings. 1995;22(1):15-24.

[38] www.electricitystorage.org [Accessed 12 March 2018]

[39] S. C. Tan, C. K. Lee, and S. Y. Hui, 'General Steady-State Analysis and Control Principle of Electric Springs With Active and Reactive Power Compensations'. IEEE Transactions on Power Electronics. 2013;28(3):3958-69.

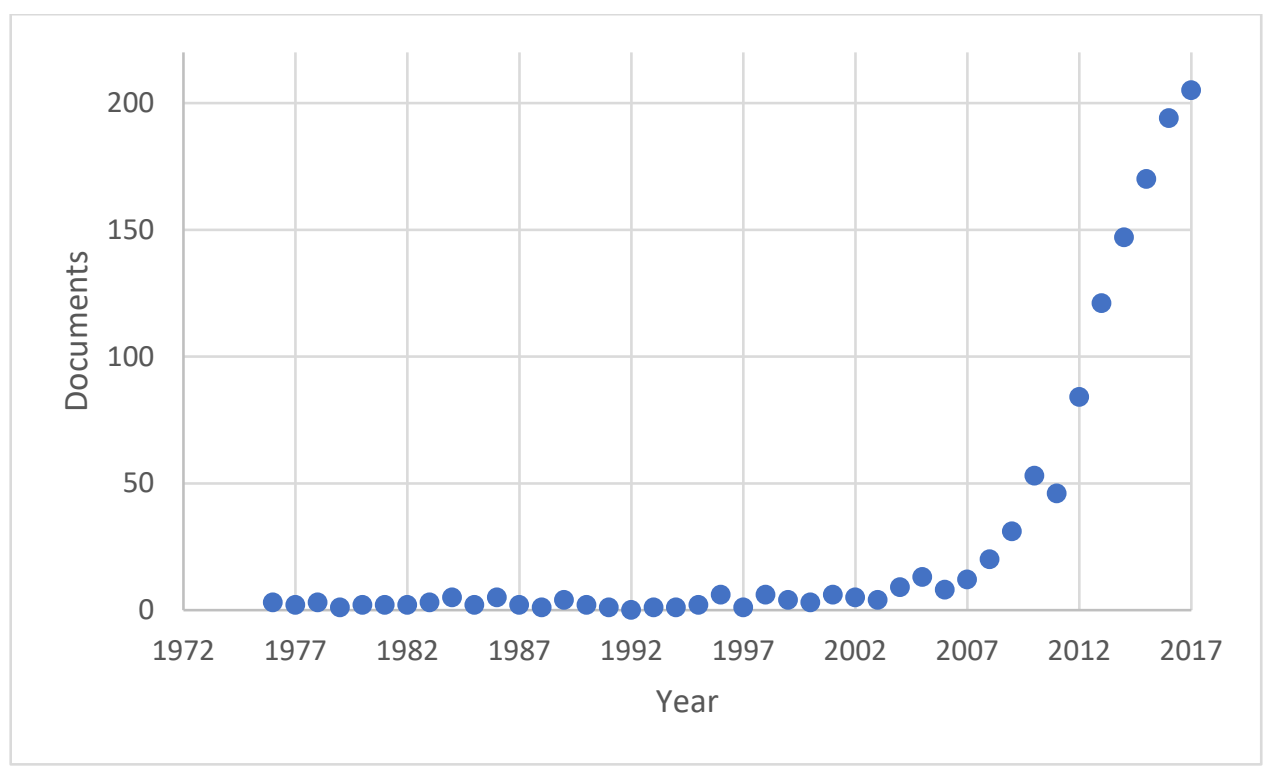

Figure 1.1: Documents by year

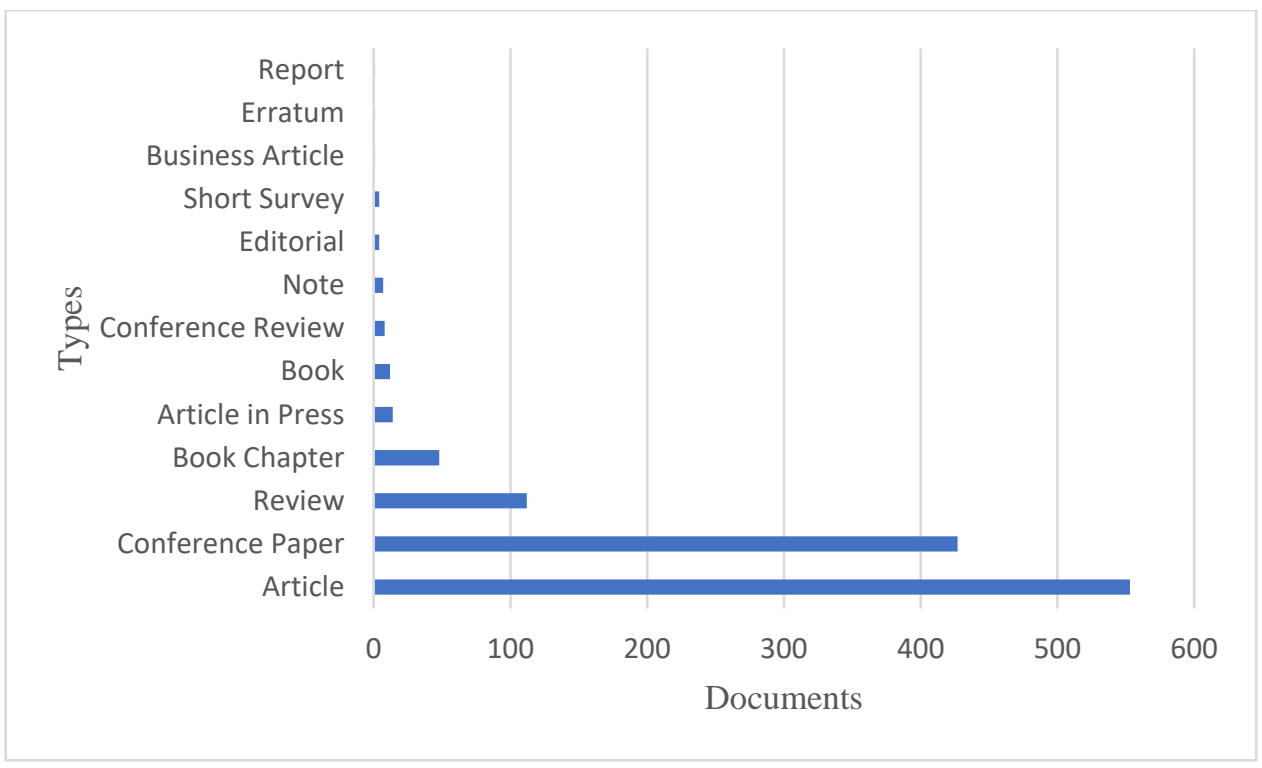

Figure 1.2: Documents by type 


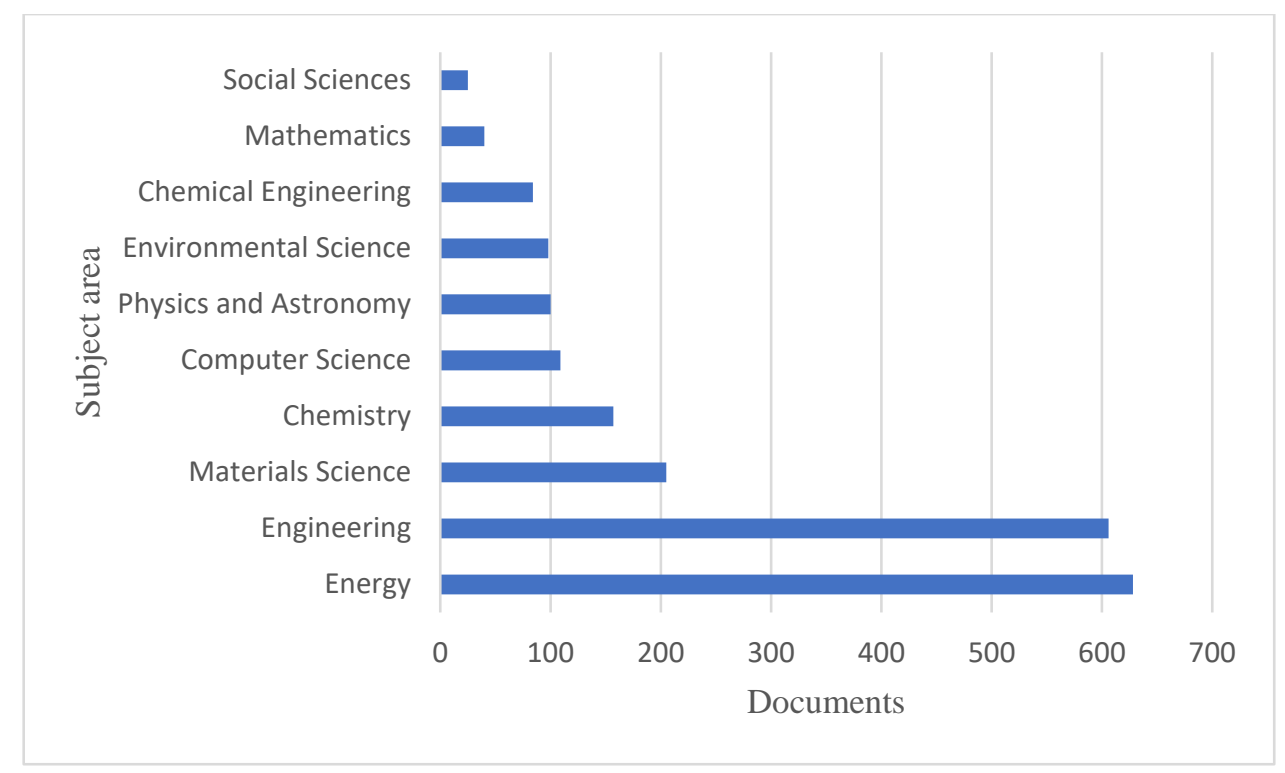

Figure 1.3: Documents by subject area

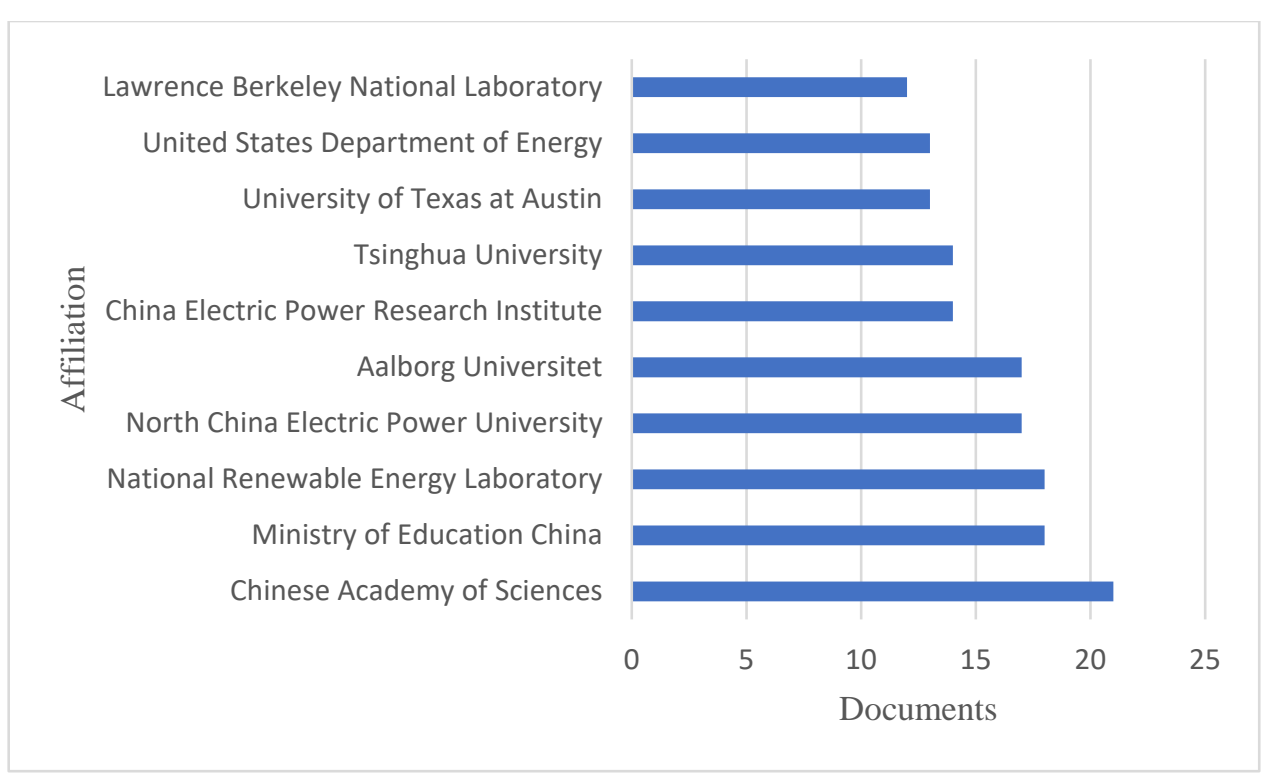

Figure 1.4: Documents by affiliation 


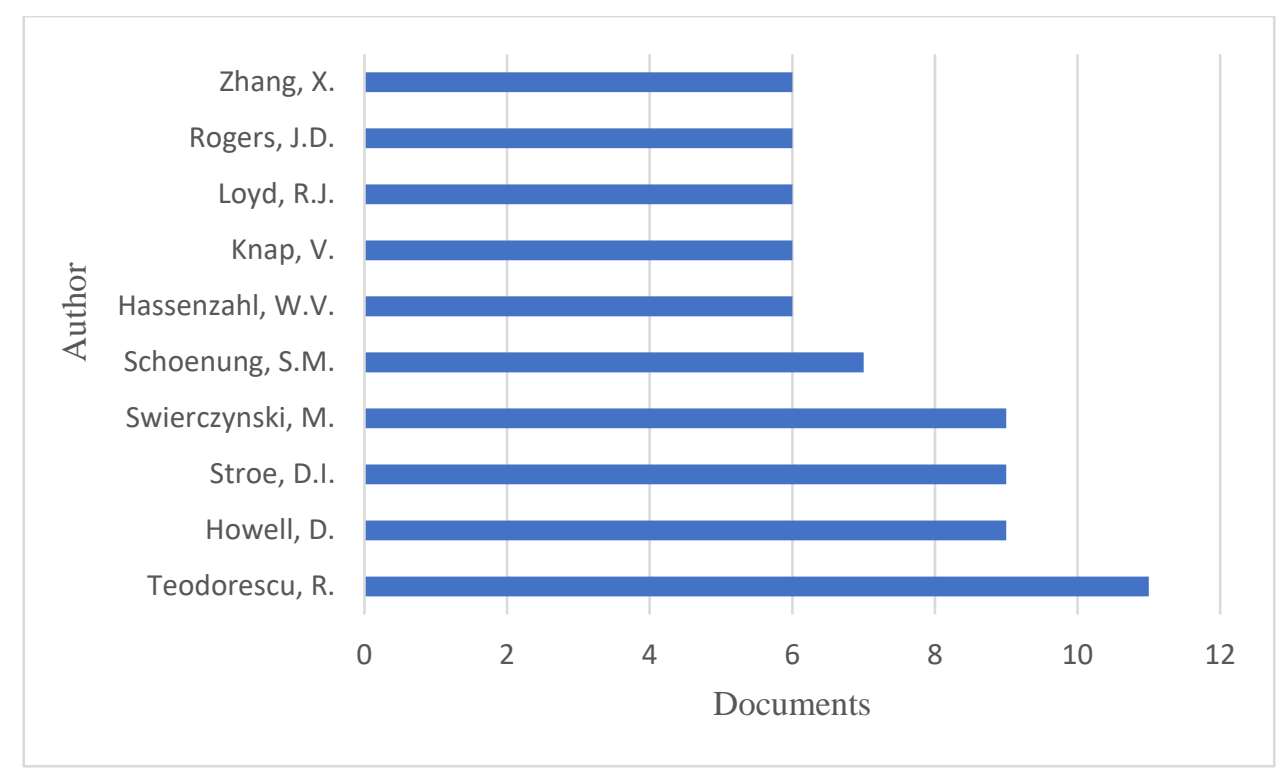

Figure 1.5: Documents by author

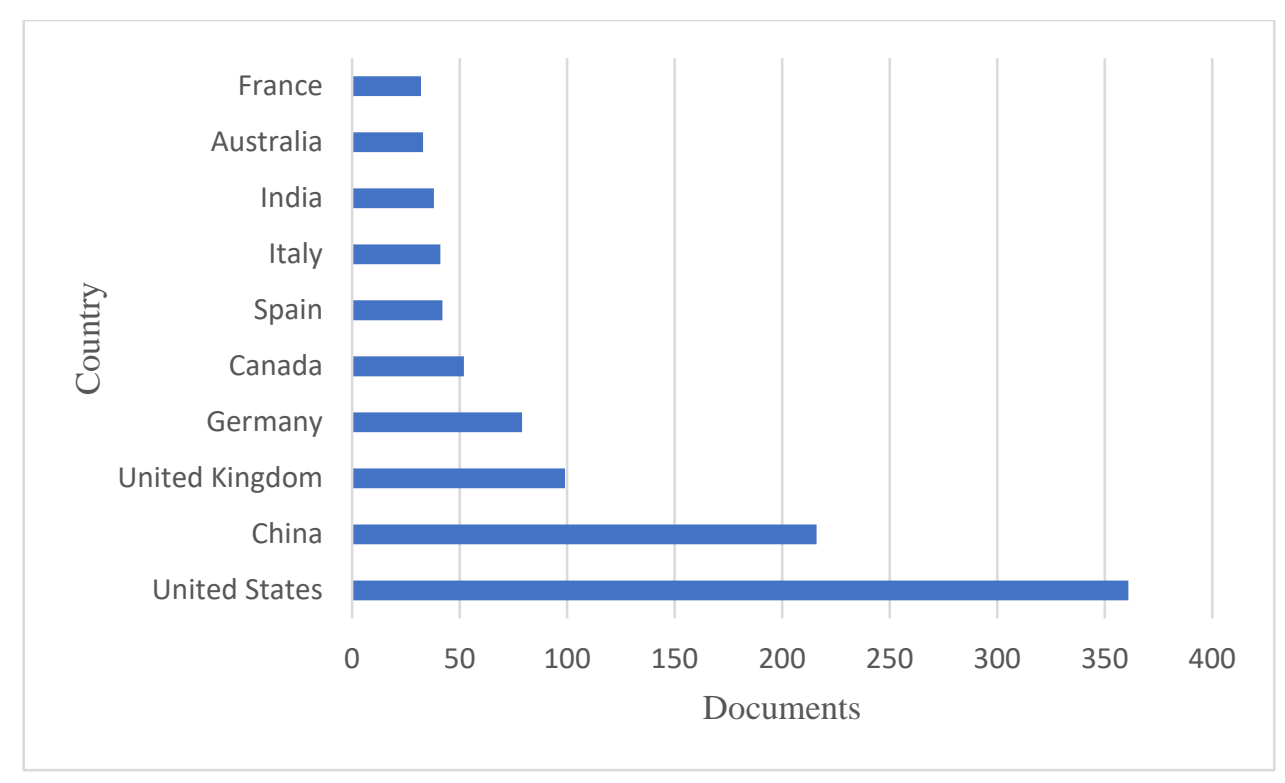

Figure 1.6: Documents by country 


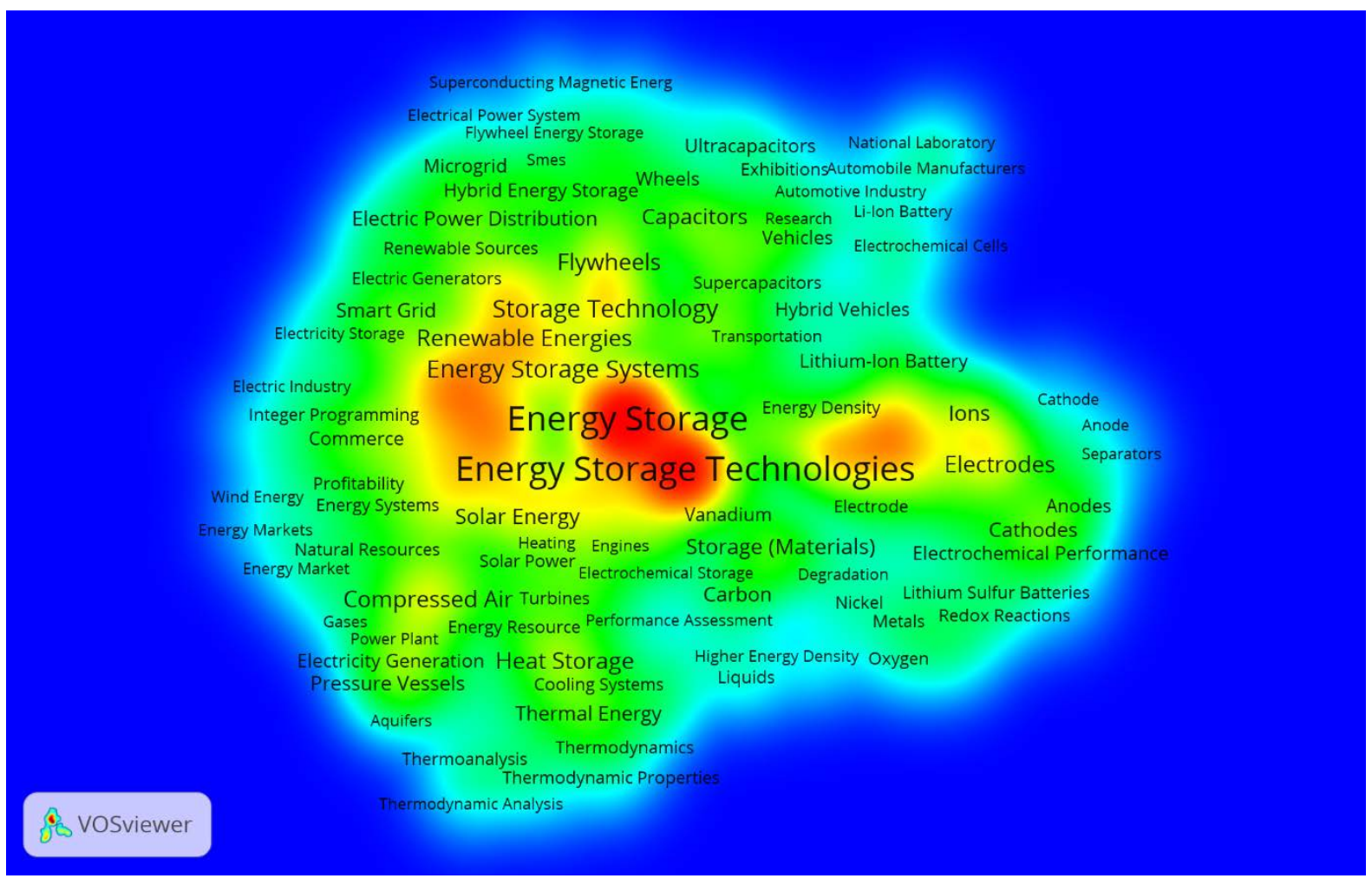

Figure 1.7: The most common keywords used in the documents

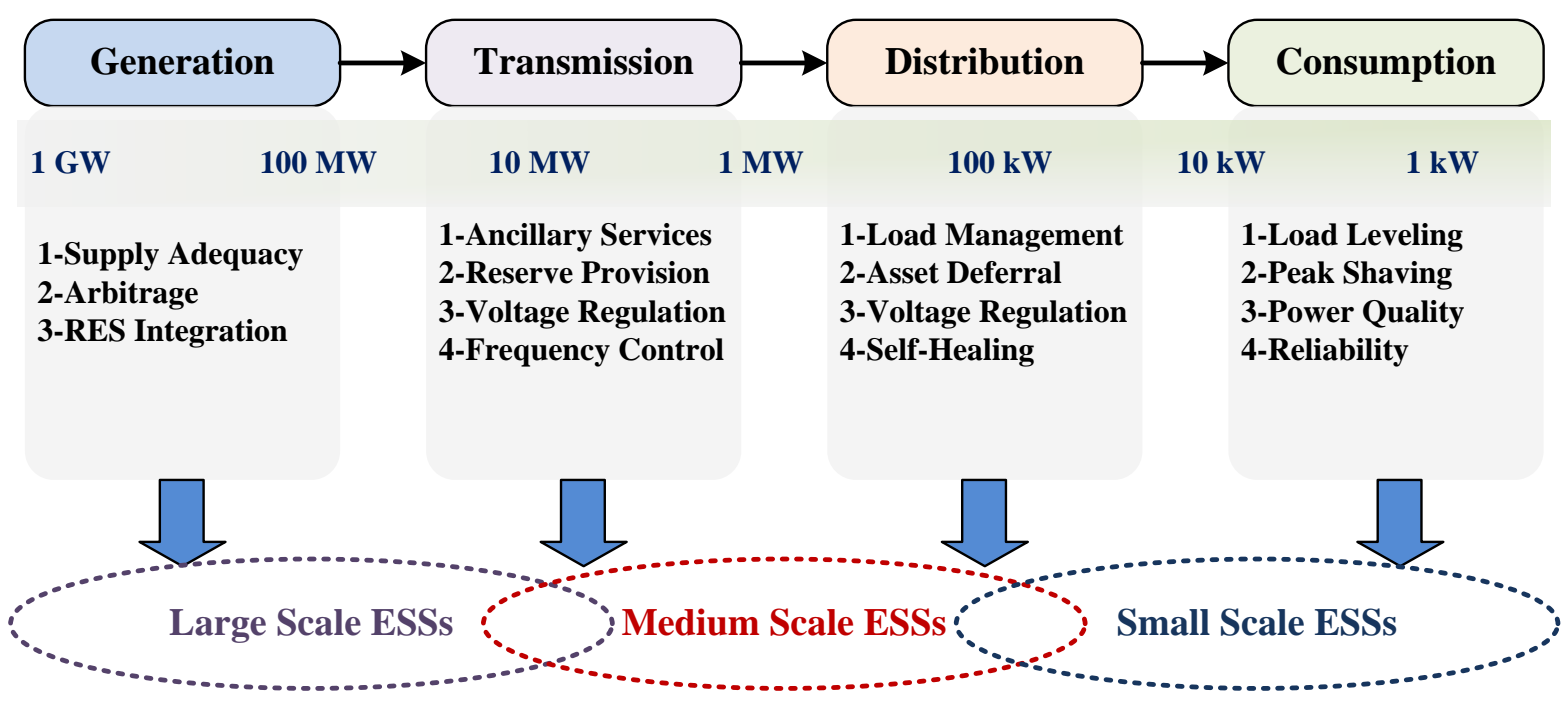

Figure 1.8: ESS various applications according to power ratings [27] 


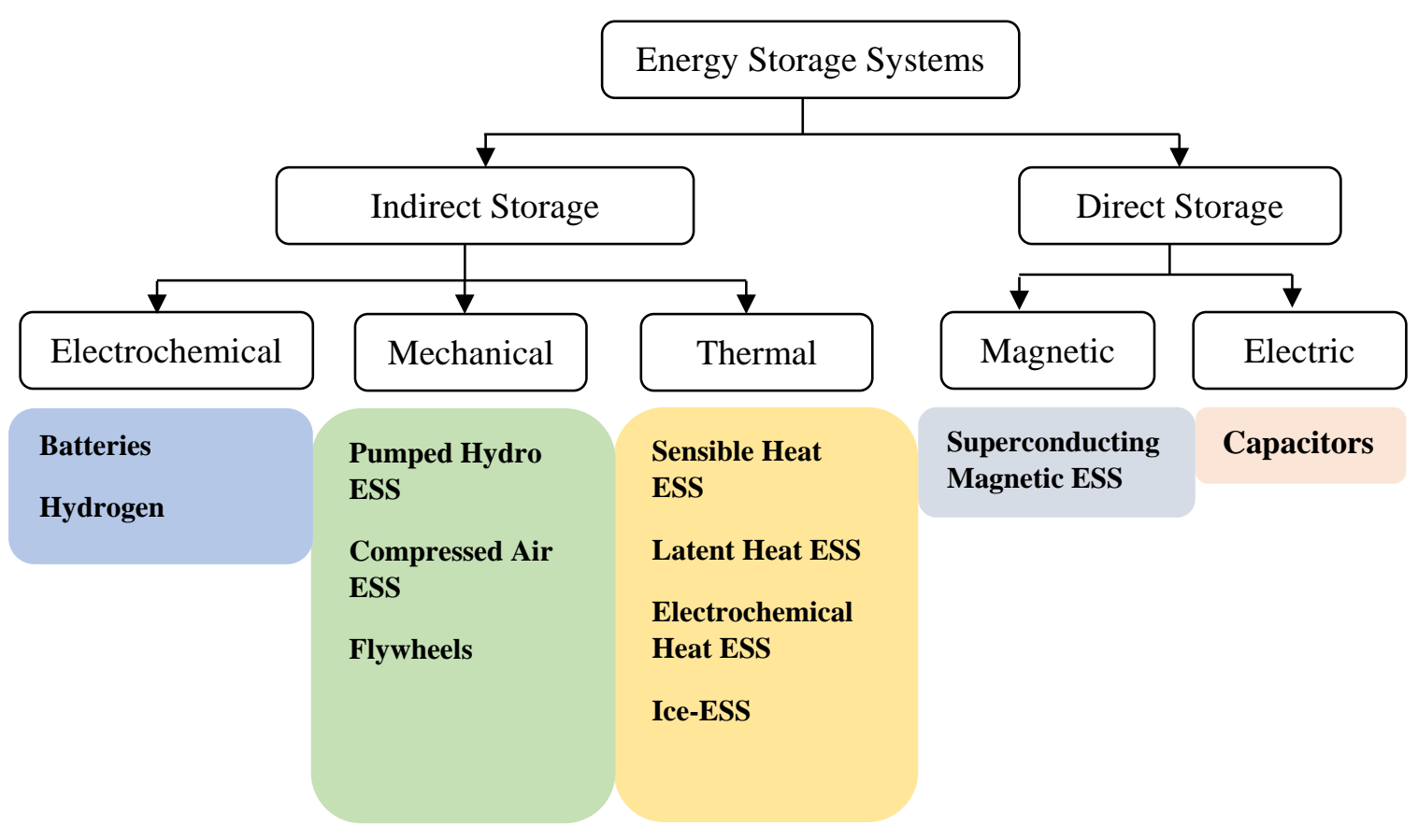

Figure 1.9: Classification of ESS technologies [8]

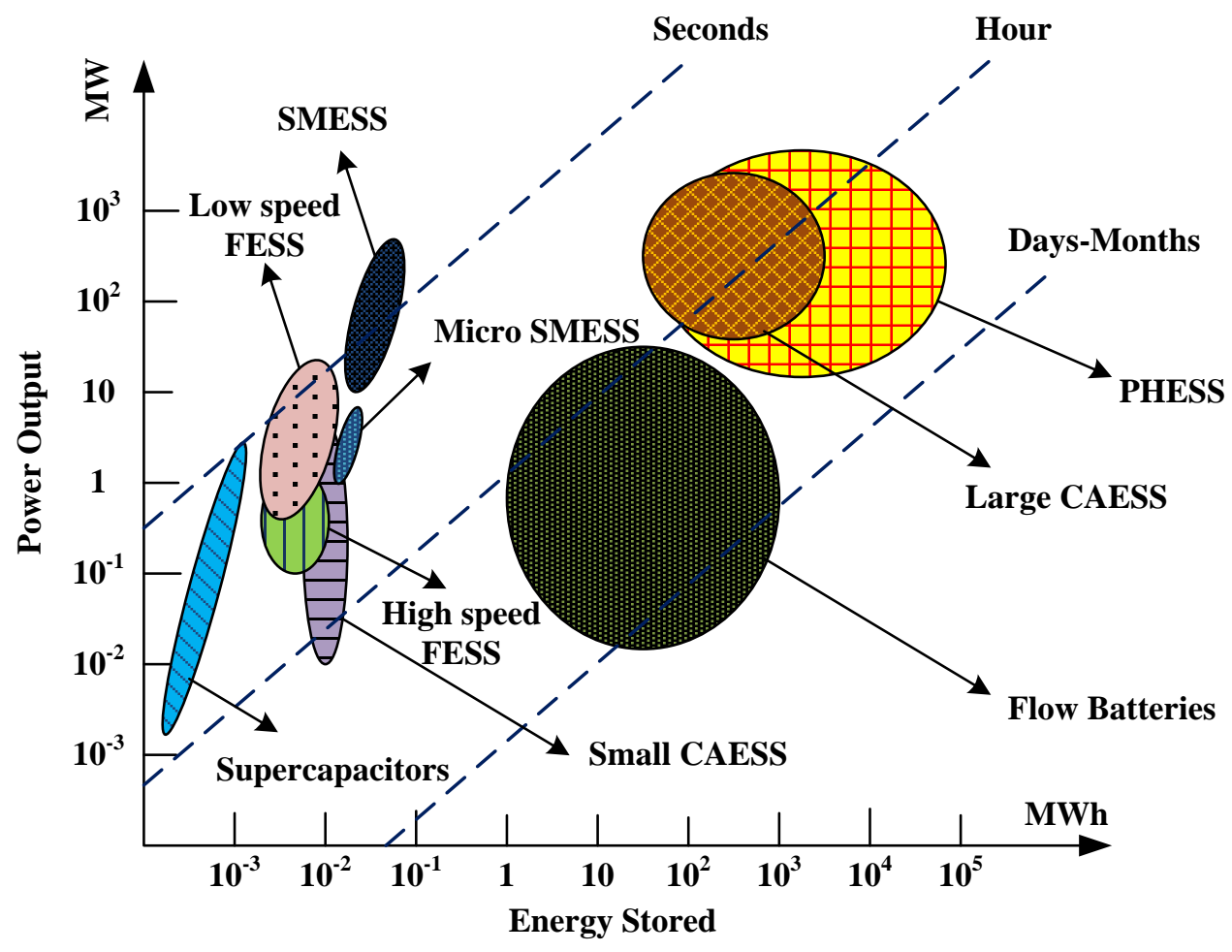

Figure 1.10: ESS technologies’ power and energy outputs [30] 

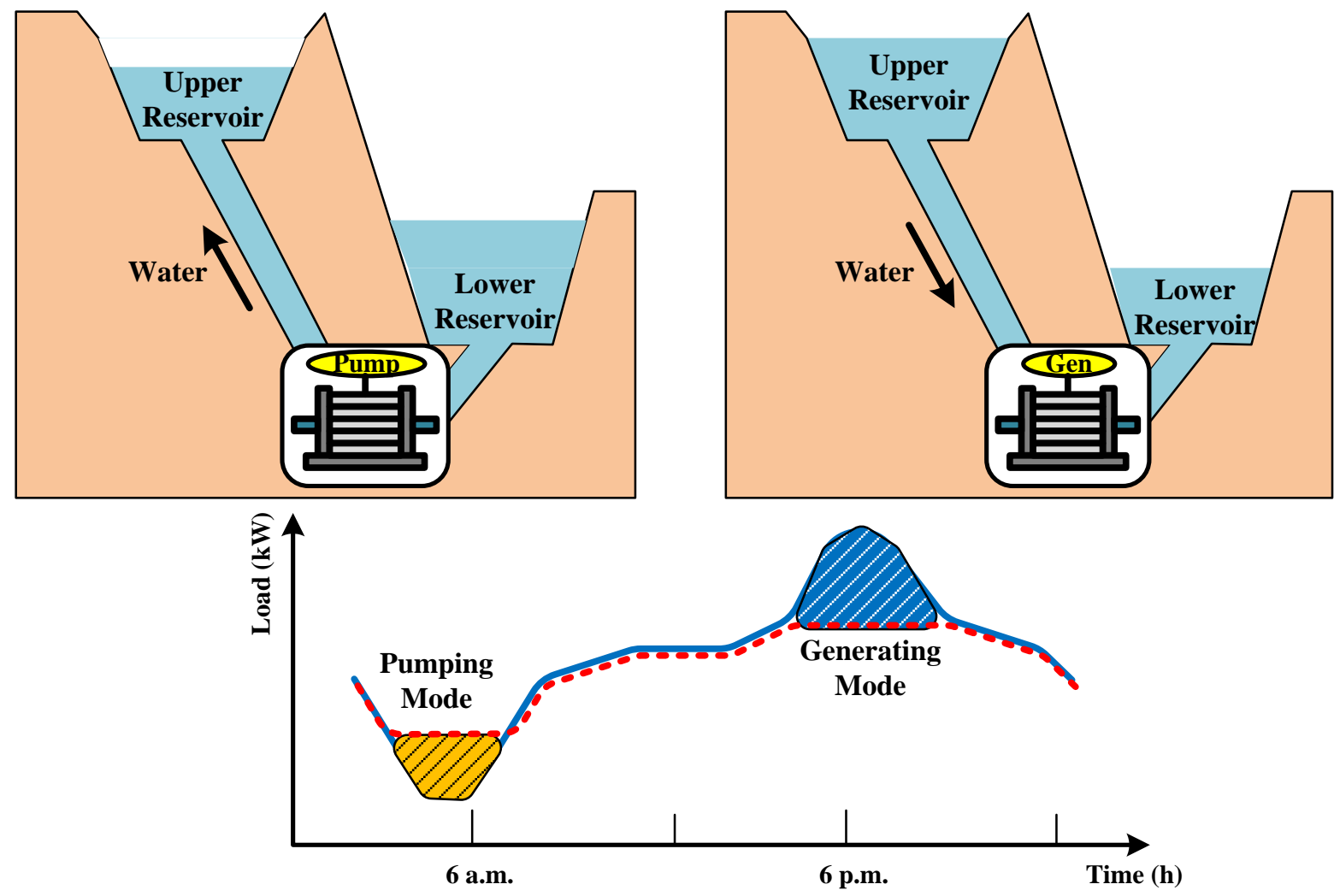

Figure 1.11: The PHESS daily performance in pumping and generating modes

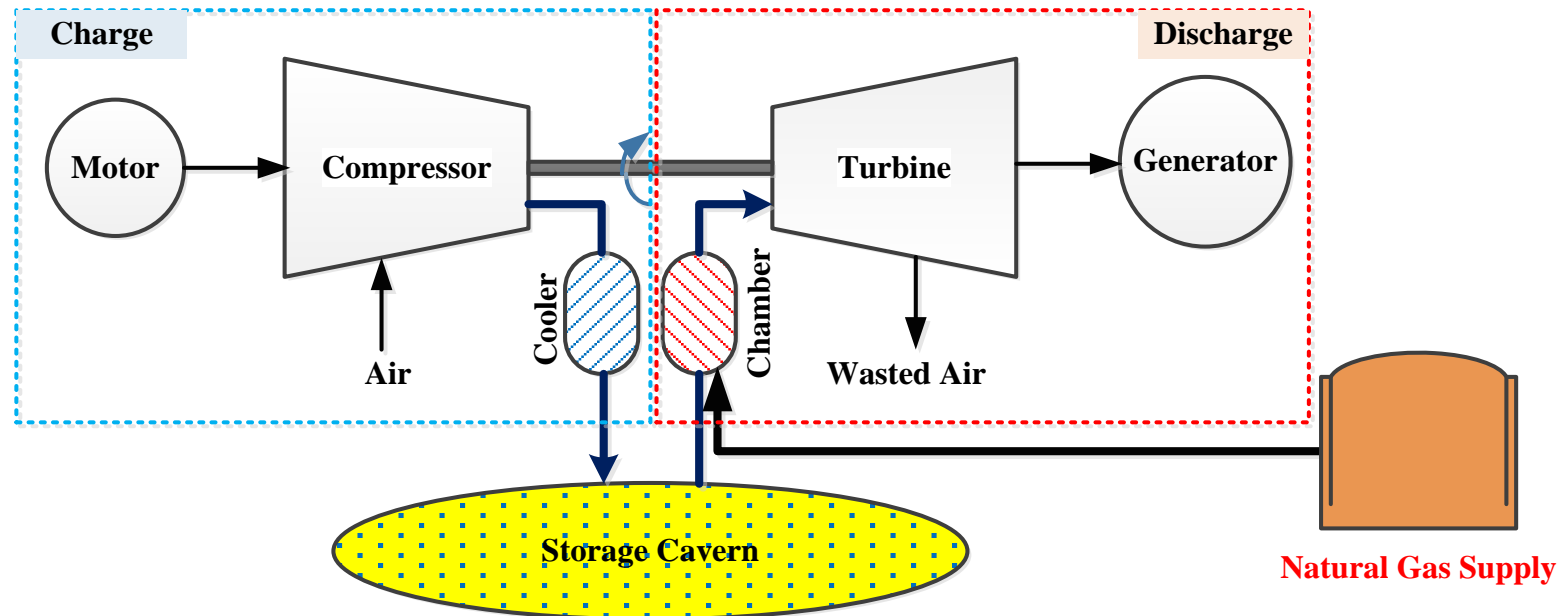

Figure 1.12: A typical CAESS structure and essential components

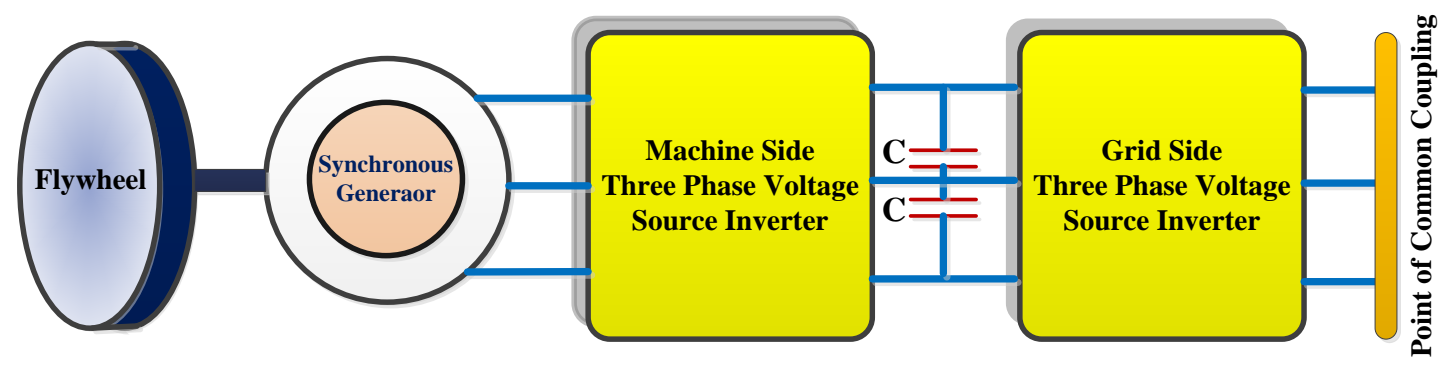

Figure 1.13: FESS model including power regulators 


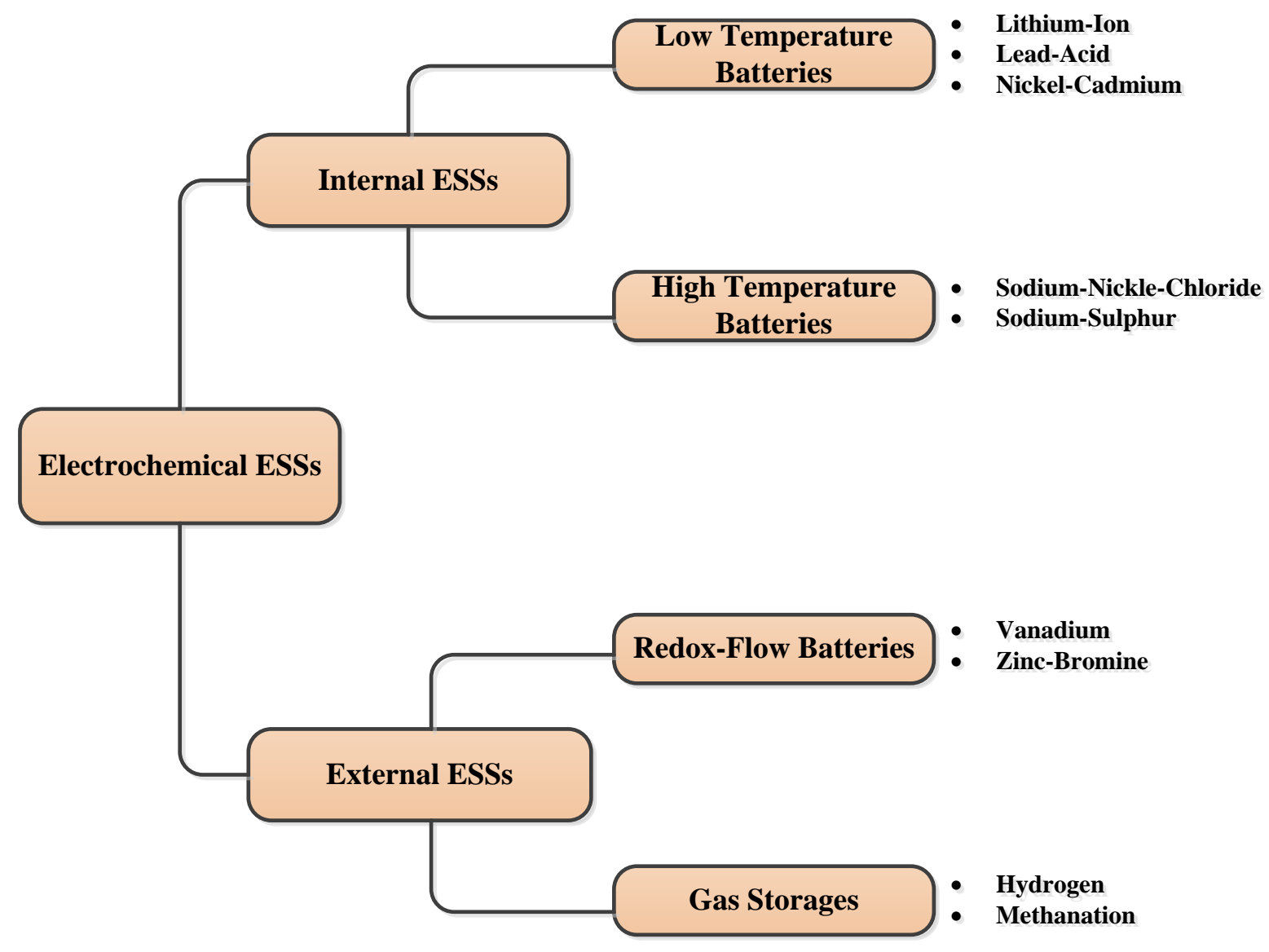

Figure 1.14: Electrochemical ESS classification

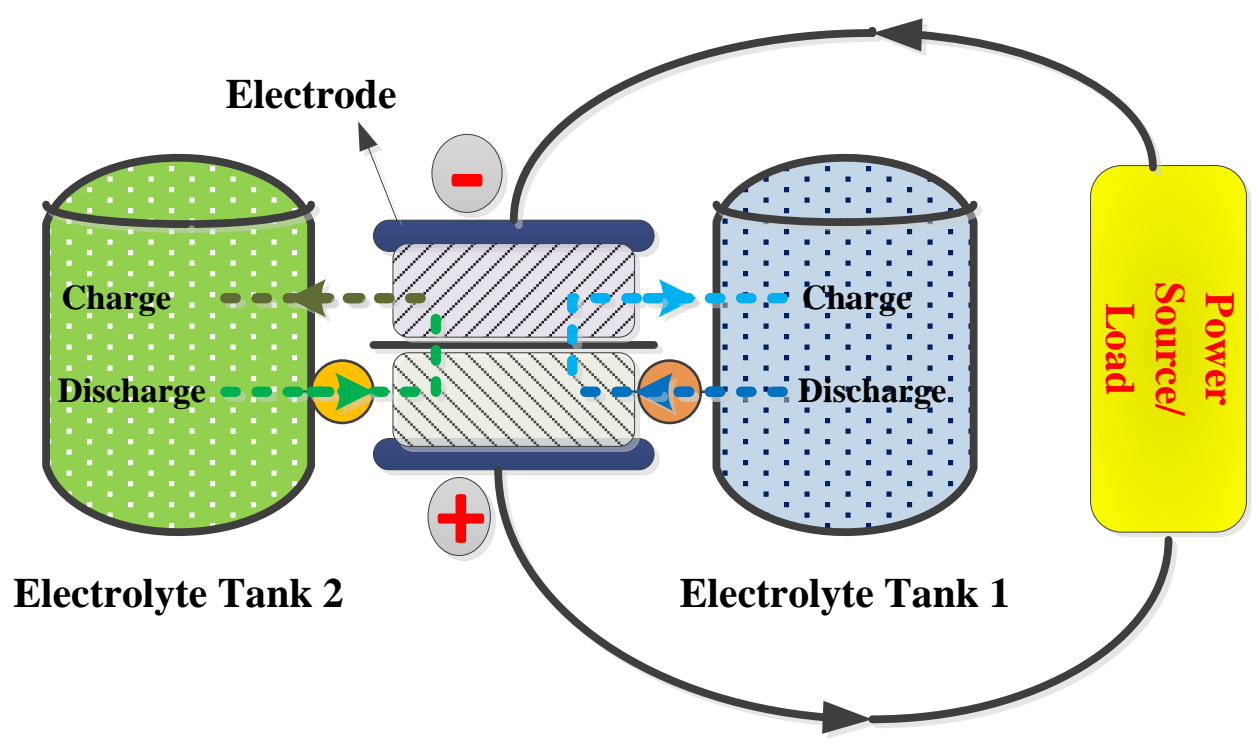

Figure 1.15: A typical flow battery illustration 


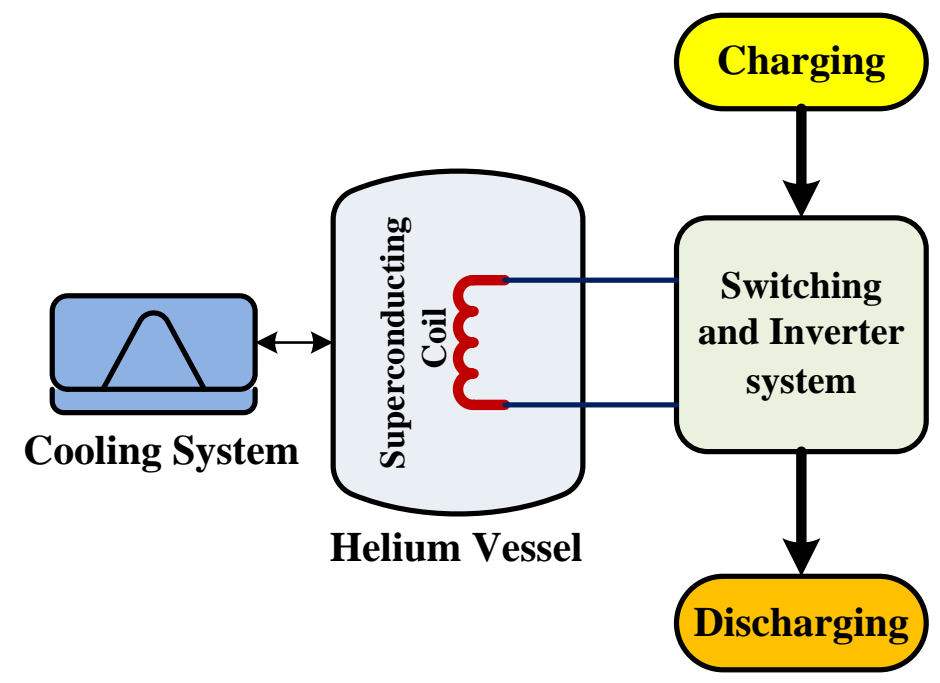

Figure 1.16: Schematic structure of a SMESS

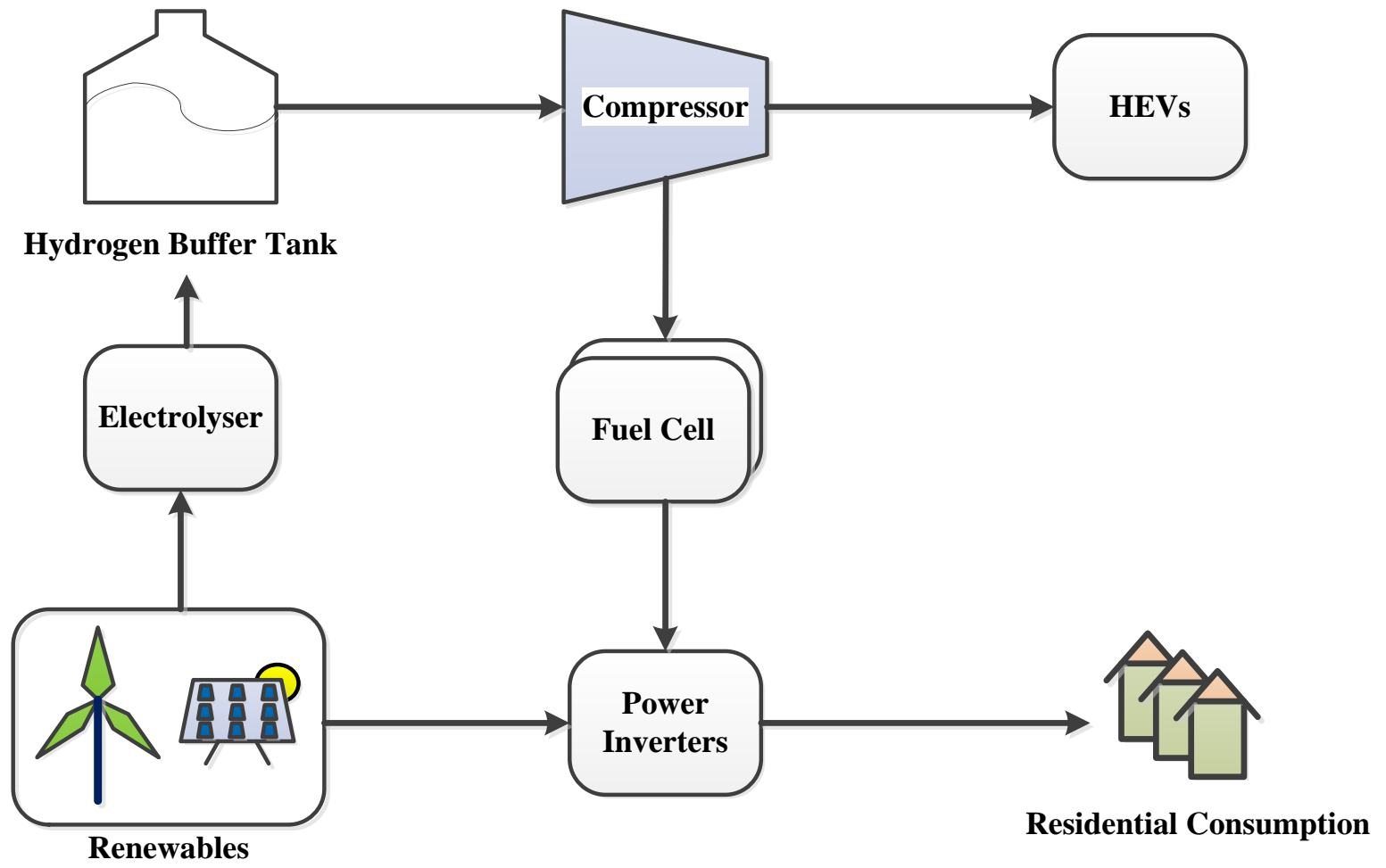

Figure 1.17: HESS process and applications 


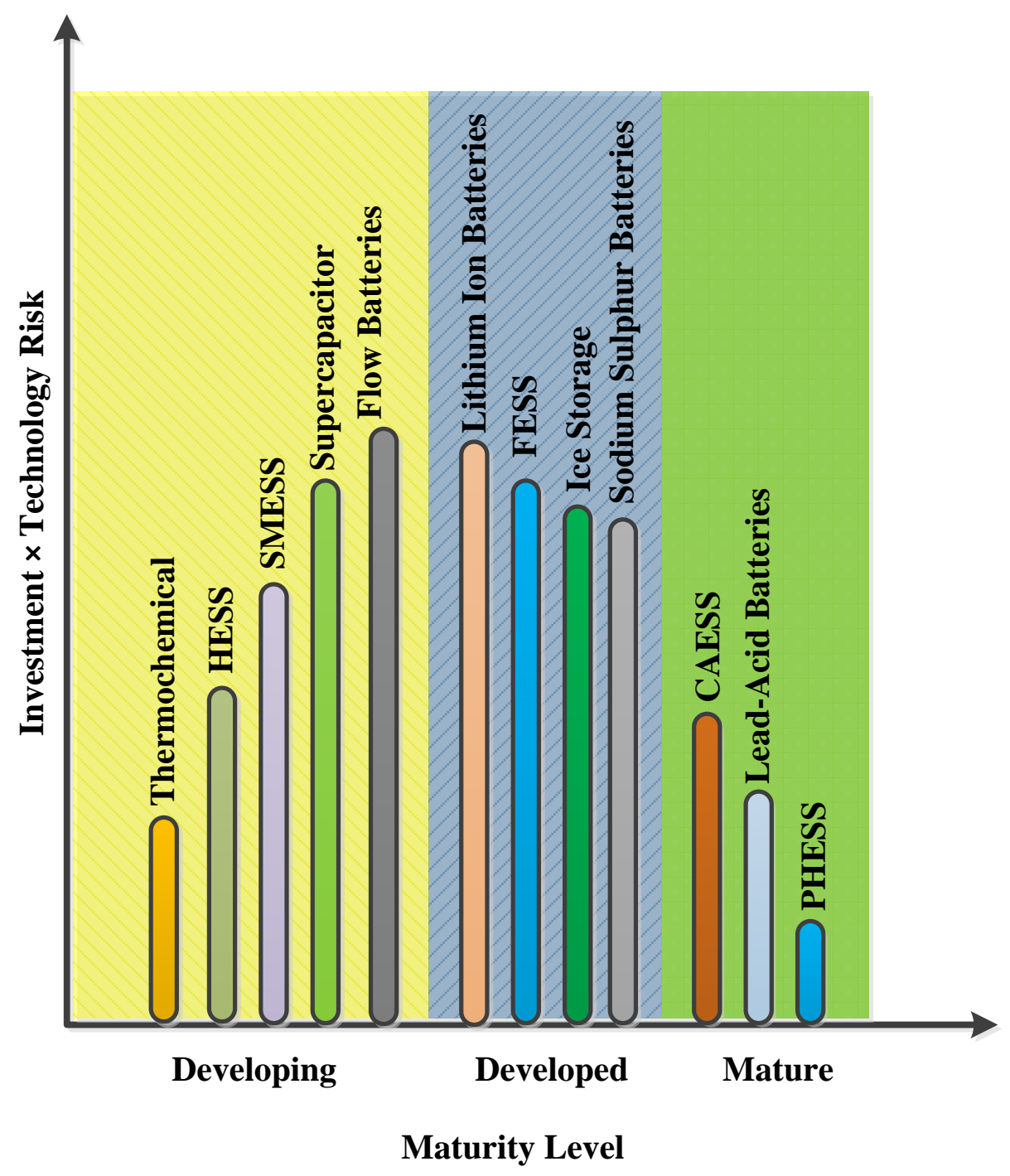

Figure 1.18: ESS technology maturity assessment [26] 


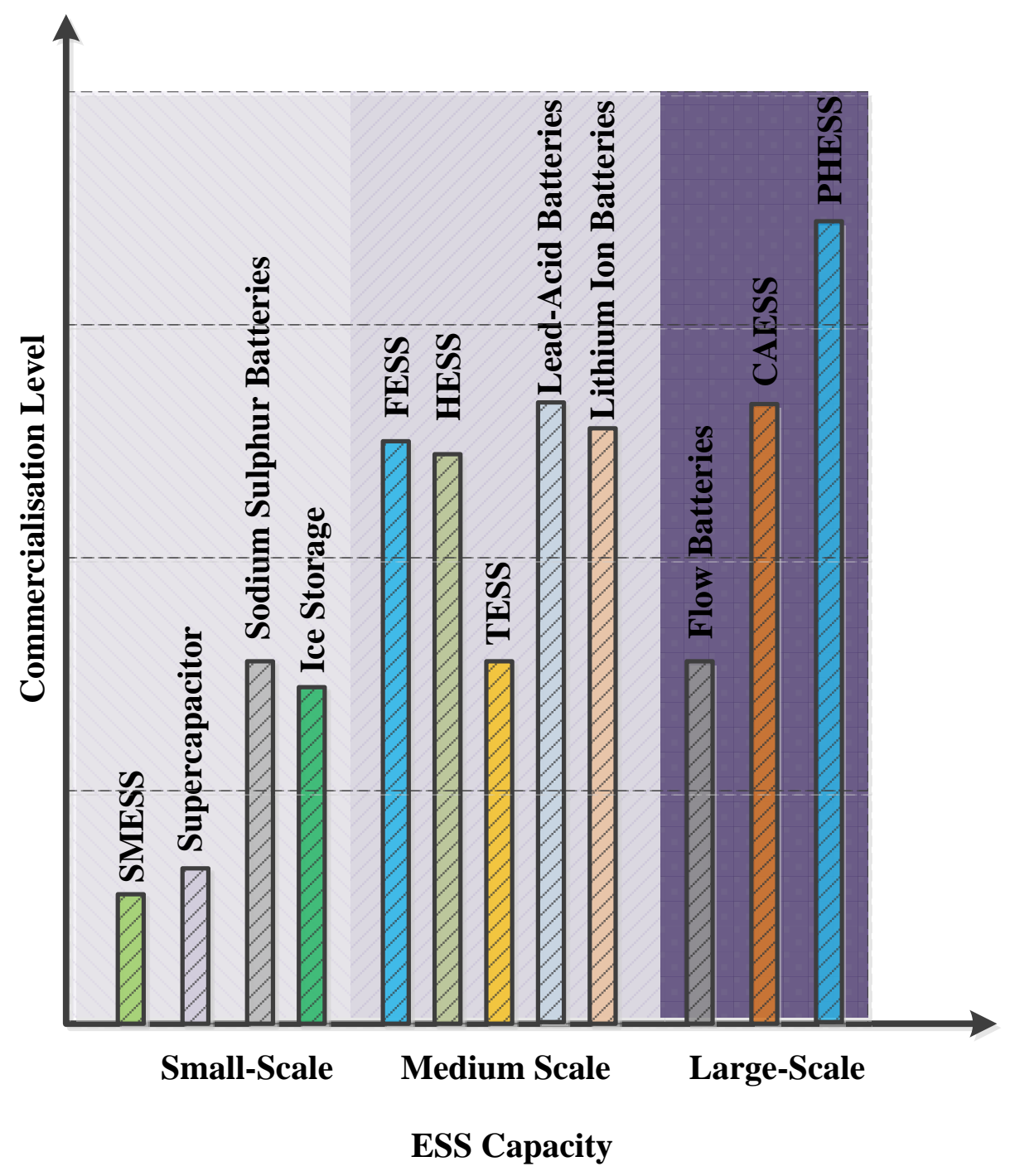

Figure 1.19: Commercialisation level of different ESS technologies [37]
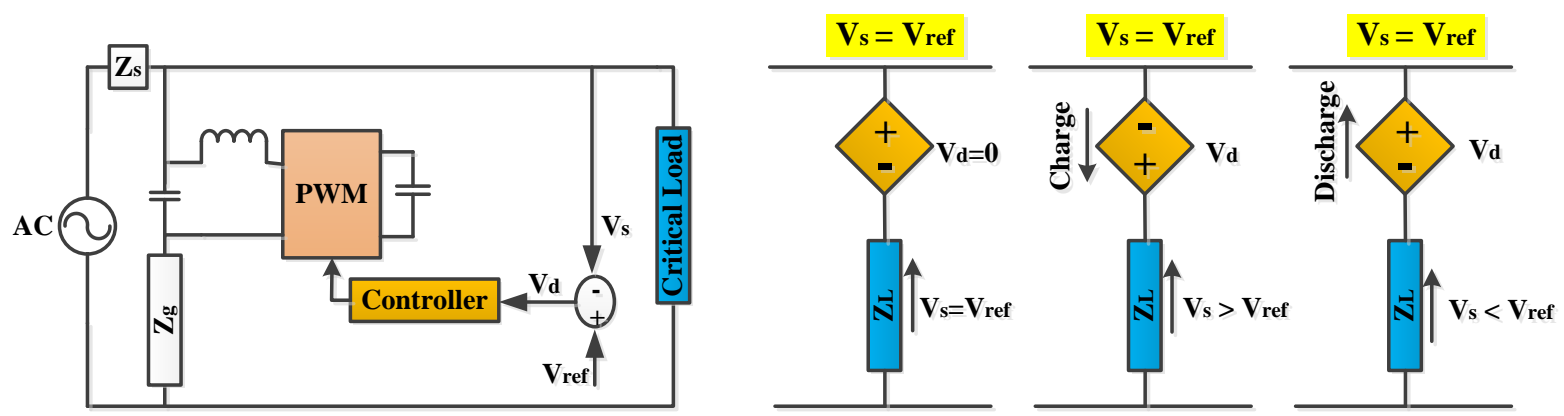

Figure 1.20: Electric spring equivalent circuit and charge/discharge modes 